\title{
High-resolution ammonium ice core record covering a complete glacial-interglacial cycle
}

\author{
Katrin Fuhrer, ${ }^{1}$ Albrecht Neftel, ${ }^{2}$ Martin Anklin, ${ }^{1}$ Thomas Staffelbach, ${ }^{2}$ and \\ Michel Legrand ${ }^{3}$
}

\begin{abstract}
High-resolution ammonium measurements were performed along the Greenland Ice Core Program (GRIP) deep ice core, covering a complete climatic cycle. No overall anthropogenic increase is observed over the last 300 years; however, springtime concentrations have roughly doubled since 1950. Biomass burning is estimated to be a major source for ammonia emissions for preindustrial times. It contributes between $10 \%$ to $40 \%$ to the total ammonium deposited on the central Greenland ice sheet during the Holocene. No correlation is found between the ammonium summer concentrations recorded over the last 100 years and the area burned in northern North America, which is considered to be the main source area for ammonium deposited on the central Greenland ice sheet. This suggests that the meteorological factor is predominant for the pattern of ammonium spikes observed in the ice core. If unchanged meteorological conditions are assumed for the Holocene, as indicated by the $\delta^{18} \mathrm{O}$ ice record, a decreasing biomass burning activity toward present time can be derived from the ammonium ice record. Soil and vegetation emissions are responsible for the ammonium background concentrations in the ice. The record therefore may be used to trace back the biomass history of the North American continent. A pronounced decreasing trend in background ammonium is found during the Holocene, reflecting decreasing temperature and therefore lower $\mathrm{NH}_{3}$ emissions in the source region. Variations in the ammonium concentration during the glacial age are discussed in terms of changes in transport and deposition mechanisms and changes in source strength, which can be related to the extent of the Laurentide ice sheet. The data suggest that the Laurentide ice sheet was built up immediately after the last interglacial and went through several large fluctuations during the last ice age.
\end{abstract}

\section{Introduction}

Ammonia is the most abundant gaseous base in the atmosphere and plays therefore an important role in the acid-base air chemistry. Ammonia is mainly released from combustion, from soils, including vegetation cover, and from bacterial decomposition of excreta, with estimated present-day contributions of $15 \%, 35 \%$, and $50 \%$, respectively, to the total ammonia emissions [Warneck, 1988]. The major part of the global presentday emissions is of anthropogenic origin, with major contributions from excreta and from fertilizer losses but also including emissions by coal combustion, burning of

\footnotetext{
${ }^{1}$ Physics Institute, University of Bern, Switzerland.

${ }^{2}$ Federal Research Institute for Agricultural Chemistry, Liebefeld, Bern, Switzerland.

${ }^{3}$ Laboratoire de Glaciologie et Geophysique de l'Environnement, CNRS, Grenoble, France.
}

Copyright 1996 by the American Geophysical Union.

Paper number 95JD02903.

0148-0227/96/95JD-02903\$05.00 plant matter in shifting agriculture, deforestation, savanna, and bushland clearings [Warneck, 1988].

The contribution of natural ammonium sources to the total emissions is not well quantified, e.g., Langford et al. [1992] estimate between 0.2 and $15 \%$ for the United States. The main natural sources are wildfires and emissions from soil and vegetation. Less than $5 \%$ of the total ammonium emissions from combustion are due to wild fires [Seiler and Crutzen, 1980]. Natural soil and plant emissions are hardly investigated in a quantitative way. Soils contain $\mathrm{NH}_{3}$ due to bacterial decomposition of plant matter, whereafter ammonia is nitrified, consumed by plants, or retained in the soil solution. It is released to the atmosphere when the ambient $\mathrm{NH}_{3}$ concentration drops below the vapor pressure of the soil solution. Soil emission will therefore depend on temperature and soil water $\mathrm{pH}$, on the soil moisture, the amount of organic nitrogen, and the populations of decomposing and nitrifying bacteria [Dawson, 1977; Langford et al., 1992]. The plant cover above the soil will interact in determining net fluxes to the atmosphere. $\mathrm{NH}_{3}$ can be directly emitted due to proteolysis during senescence of plants [Whitehead and Lockyer, 1989]. There will be a 
net $\mathrm{NH}_{3}$ emission from vegetation if the ambient $\mathrm{NH}_{3}$ concentration is lower than the "canopy compensation point", which characterizes the partial pressure of ammonia in the substomatal cavities and on the leaf surface [Lövblad et al., 1993; Langford et al., 1992]. Otherwise, there will be a net uptake of ammonia. A wide variety of ambient ammonium concentrations is found above different natural ecosystems (review by Langford et al. [1992]), reflecting the complex interplay of the above parameters. However, the overall processes at play are not well understood. Also, the ocean may be a net source for $\mathrm{NH}_{3}$ [Quinn et al.; 1990] but there remain large uncertainties for the estimate of the marine $\mathrm{NH}_{3}$ budget [Sutton et al., 1994]. Talbot et al. [1992] suggested that rotting sea ice emits ammonia, but the extent of the emissions is not quantified. The main sinks for atmospheric $\mathrm{NH}_{x}\left(\mathrm{NH}_{3}\right.$ and $\left.\mathrm{NH}_{4}^{+}\right)$are wet and dry deposition. $\mathrm{NH}_{3}$ dry deposition is very efficient on soils and plant covers with compensation points below the ambient ammonia concentration and constitutes the dominating deposition mechanism for $\mathrm{NH}_{3}$. The deposition velocity above soils and plant cover is an order of magnitude larger for $\mathrm{NH}_{3}$ than for $\mathrm{NH}_{4}^{+}$[Lövblad et al., 1993]. $\mathrm{NH}_{3}$ can be taken up into acidic aerosols and be converted into $\mathrm{NH}_{4}^{+}$. As long as sulfate is available, $\mathrm{NH}_{3}$ will preferentially form $\mathrm{NH}_{4} \mathrm{HSO}_{4}$ and $\left(\mathrm{NH}_{4}\right)_{2} \mathrm{SO}_{4}$, which is an irreversible process (due to a very low vapor pressure of ammonia above sulfuric acid), in contrary to the formation of $\mathrm{NH}_{4} \mathrm{NO}_{3}$. The lifetime of $\mathrm{NH}_{3}$ in the boundary layer is estimated to about 1 day [Asman and Jansson, 1987] and that of $\mathrm{NH}_{4}^{+}$to several days [Warneck, 1988]. Therefore mostly $\mathrm{NH}_{4}^{+}$will be transported over long distances [Asman and Jansson, 1987; Langford et al., 1992]. If $\mathrm{NH}_{3}$ reaches the free troposphere, the lifetime of $\mathrm{NH}_{4}^{+}$and $\mathrm{NH}_{3}$ are similar due to comparable scavenging efficiencies. Ammonia concentration in the atmosphere above natural ecosystems mostly exhibits a pronounced seasonal and diurnal cycle [Warneck, 1988], with an exponential temperature dependence [Langford et al., 1992]. This supports the importance of soil bacteria activity [Warneck, 1988]. The seasonality is less pronounced, however, in agricultural areas [Langford et al., 1992; Nodop, 1990]

Ammonium measurements in precipitation have been performed as early as at the end of the last century (summarized by Brimblecombe and Stedman [1982]) at agricultural sites. They show a large scatter and it is difficult to identify trends due to their large local and annual variability. Measurements in remote regions avoid the variability caused by the vicinity of sources. Especially, polar ice sheets are well suited for observing the background atmosphere due to their high elevation: precipitation on polar ice sheet may reflect the free troposphere. Measurements on ice cores are the only means to provide direct insight into the cycling of $\mathrm{NH}_{x}$ in the preindustrial and paleotimes. We performed measurements of ammonium along the Green- land Ice Core Project (GRIP) deep core, in central Greenland $\left(72.58^{\circ} \mathrm{N}, 37.64^{\circ} \mathrm{W}\right)$, which covers at least the last 100,000 years, a full glacial-interglacial cycle [Dansgaard et al., 1993].

\section{Methods}

All ammonium results presented here were obtained from analyses performed directly in the field, to minimize contamination due to transport, storage, handling, and exposure of the samples to the laboratory atmosphere. The firn measurements were performed within 2 days after the core retrieval, all other measurements within a few days to a month after core recovery. The analytical method used was a continuous flow analysis (CFA) . Ammonium was detected through the reaction with o-phthaldialdehyde [Genfa and Dasgupta, 1989] yielding a fluorescence product. A specially designed melt device was used to avoid contamination [Sigg et al., 1994], allowing to analyze the inner part of the sample which is not exposed to the surrounding atmosphere.The geometry of the CFA system leads to a mixing (dispersion) corresponding to less than $1 \mathrm{~cm}$ of core length, which is the limiting factor for the depth resolution of the data set. Therefore we obtain a very high depth and time resolution, respectively, compared to conventional sampling methods [e.g., Whitlow et al., 1992; Legrand and deAngelis, 1995]. The time resolution is less than a month at present time and about 2 years at 100,000 years B.P. Recursive filtering can improve the depth resolution partly leading to a reconstruction of the original signal [Sigg et al., 1994]. The statistical analysis we performed gave the same results within a $5 \%$ limit for the filtered and the untreated data. We therefore discuss the untreated record except where specified.The detection limit of the setup is around $0.1 \mathrm{ppb}$. Parallel measurements along the same core showed very reproducible results. A detailed description of the analytical technique is given by Sigg et al. [1994].

The calcium results between 1300 and $2280 \mathrm{~m}$ were measured with an absorption method described by Kagenow [1982]. The rest of the core was analyzed by a fluorescence reaction with the indicator quin-2 [Clarke et al., 1988].

\section{Data}

Ammonium concentrations have been measured continuously along the depth intervals $100-600 \mathrm{~m}, 1300-$ $2060 \mathrm{~m}$, and $2280-3020 \mathrm{~m}$, corresponding to the time intervals of $300-3000$ years B.P., $8000-25,000$ years B.P., and 40,000 to at least 100,000 years B.P. Only a few meters wcre measured continuously between 600 and $1300 \mathrm{~m}$ due to the poor core quality in this section. In 1993, continuous ammonium measurements were also performed along a 100-m core from Summit, to cover 
Table 1. Summary of Published Ammonium Data From the Summit Region

\begin{tabular}{|c|c|c|c|c|}
\hline Time Period & $\mathrm{NH}_{4}^{+}$Averages & $\mathrm{NH}_{4}^{+}$Winter Values & Reference & Location \\
\hline \multicolumn{5}{|c|}{ Short-Term Records (Pit Studies) } \\
\hline $\begin{array}{l}1983-1990 \\
1983-1991 \\
1978-1987 \\
1978-1987\end{array}$ & $\begin{array}{l}6.34 \\
7.2 \\
6.24 \\
9.08\end{array}$ & $\begin{array}{c}1-3 \\
1-3 \\
1-3 \\
3.5-7\end{array}$ & $\begin{array}{c}\text { this work } \\
\text { Silvente and Legrand [1993] } \\
\text { this work } \\
\text { Whitlow et al. }[1992]\end{array}$ & $\begin{array}{r}72.58^{\circ} \mathrm{N}, 37.64^{\circ} \mathrm{W} \\
72.57^{\circ} \mathrm{N}, 37.63^{\circ} \mathrm{W} \\
72.58^{\circ} \mathrm{N}, 37.64^{\circ} \mathrm{W} \\
72.2^{\circ} \mathrm{N}, 37.8^{\circ} \mathrm{W}\end{array}$ \\
\hline \multicolumn{5}{|c|}{ Long-Term Records } \\
\hline $\begin{array}{c}1750-1989 \\
1750-1989 \\
1767-1970 \\
60 \text { years in } \\
1733-1985\end{array}$ & $\begin{array}{l}5.71 \\
5.89 \\
5.46 \\
3.48\end{array}$ & & $\begin{array}{c}\text { this work } \\
\text { Whitlow et al. }[1994] \\
\text { Legrand and deAngelis [1995] } \\
\text { Laj et al. }[1992]\end{array}$ & $\begin{array}{r}72.58^{\circ} \mathrm{N}, 37.64^{\circ} \mathrm{W} \\
72.2^{\circ} \mathrm{N}, 37.8^{\circ} \mathrm{W} \\
72.58^{\circ} \mathrm{N}, 37.64^{\circ} \mathrm{W} \\
71^{\circ} \mathrm{N}, 36^{\circ} \mathrm{W}\end{array}$ \\
\hline
\end{tabular}

All concentrations are given in parts per billion.

the last 300 years. The timescale used from 100 to 3000 $\mathrm{m}$ is published by Johnsen et al. [1992] and Dansgaard et al. [1993]. The 100-m core was dated by annual layer counting based on the calcium and ammonium seasonal variations. Reference horizons from volcanoes (H.B. Clausen, personal communication, 1995) confirmed the established timescale. Since coritamination problems are significant for ammonium measurements [Whitlow et al., 1994], only a few ammonium data from Greenland ice cores and pit studies are published so far [ Mayewski et al., 1994; Whitlow et al., 1992, 1994; Fuhrer et al., 1993; Laj et al., 1992; Legrand and deAngelis, 1995, this issue; Silvente and Legrand, 1993; Busenberg and Langway, 1975]. Most of them report data from the Summit area. Average concentrations of roughly the last 200 years from the continuous records published by Legrand and deAngelis [this issue] and Whitlow et al. [1994] compare well with our record (Table 1) as well as concentrations published by Mayewski et al. [1994] between 10,000 and 15,000 years B.P. Specifically, therc is a good correspondence for low winter concentrations (Table 1) and the occurrence of large ammonium spikes in our record and that of Legrand and deAngelis [this issue]. For the purpose of comparison of the high spikes in the different data sets from the Summit area, annual mean values (respective biannual ones for the record by Whitlow et al. ) are shown in Figure 1. Since high spikes largely dominate the yearly means, differences in the annual mean concentration between the different records originate mainly from differences in the high spikes. Our record and that of Legrand and deAngelis [this issue] were retrieved from two cores which were drilled only $300 \mathrm{~m}$ apart. Concluding from these two data sets, the local variability is large for high spikes (Figure 1). This is most probably due to reworking of the snow surface by drifting snow, changing the layer thicknesses of the chemical horizons [Jaffrezo et al., 1995]. This can also explain the different concentra-

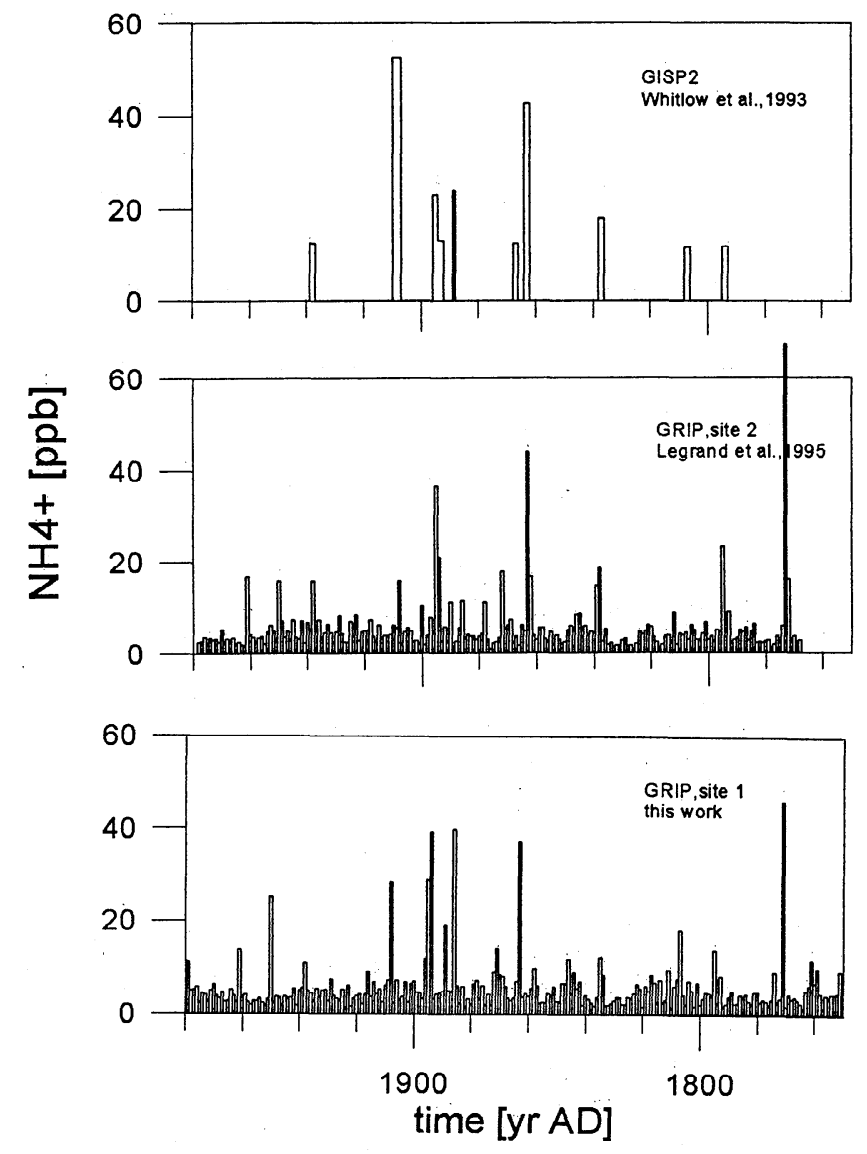

Figure 1. Mean annual concentrations from our record are shown as well as mean annual concentrations for years with high spikes from Legrand and deAngelis [this issue]. The two cores were drilled roughly $300 \mathrm{~m}$ apart. The dating precision for our record is 1 year; for the record from Legrand and deAngelis [this issue] it is 1 year down to 1890 and 2 years farther down. The missing spike at 1807 in the data set from Legrand and deAngelis [this issue] is due to a gap in the sampling. The spike record from the GISPII record is taken from Whitlow et al. [1992]. The resolution is about biannual. 
tions found in different pit studies (Table 1), covering only a short time period.

The ammonium spike record from about biannual samples by Whitlow et al. [1994] is partly in agreement with our record (Figure 1); however, large spikes such as 1950, 1961, and 1770 are not reported there. A part of the reasons for the discrepancies may be the lower time resolution of the record by Whitlow et al. [1994], dating uncertainties and local variability. The lower resolution of the record by Laj et al. [1992] may be the reason for the disagreement with our record (Table 1).

The interpretation of chemical ice records in terms of changing atmospheric concentration or in source strength, is not straightforward. The relationship between the local atmospheric and ice concentration is called the transfer function. For the interpretation of ice records a main interest is the understanding of how much the transfer function is affected by changing glaciometeorological conditions. This includes relative changes in the contribution of the deposition mechanisms and absolute changes in dry deposition velocity, scavenging ratio, fog frequency, and in sublimation of snow. The amount of ammonium deposited on the ice sheet can also change when the processes involved in the transport of $\mathrm{NH}_{x}$ from the source region to the local atmosphere over Summit change. There is evidence that for a fixed air concentration the sum of these mechanisms tends to increase the concentration of aerosols in ice with lower accumulation rate and colder climate [Legrand, 1995; Cunningham and Waddington, 1993].

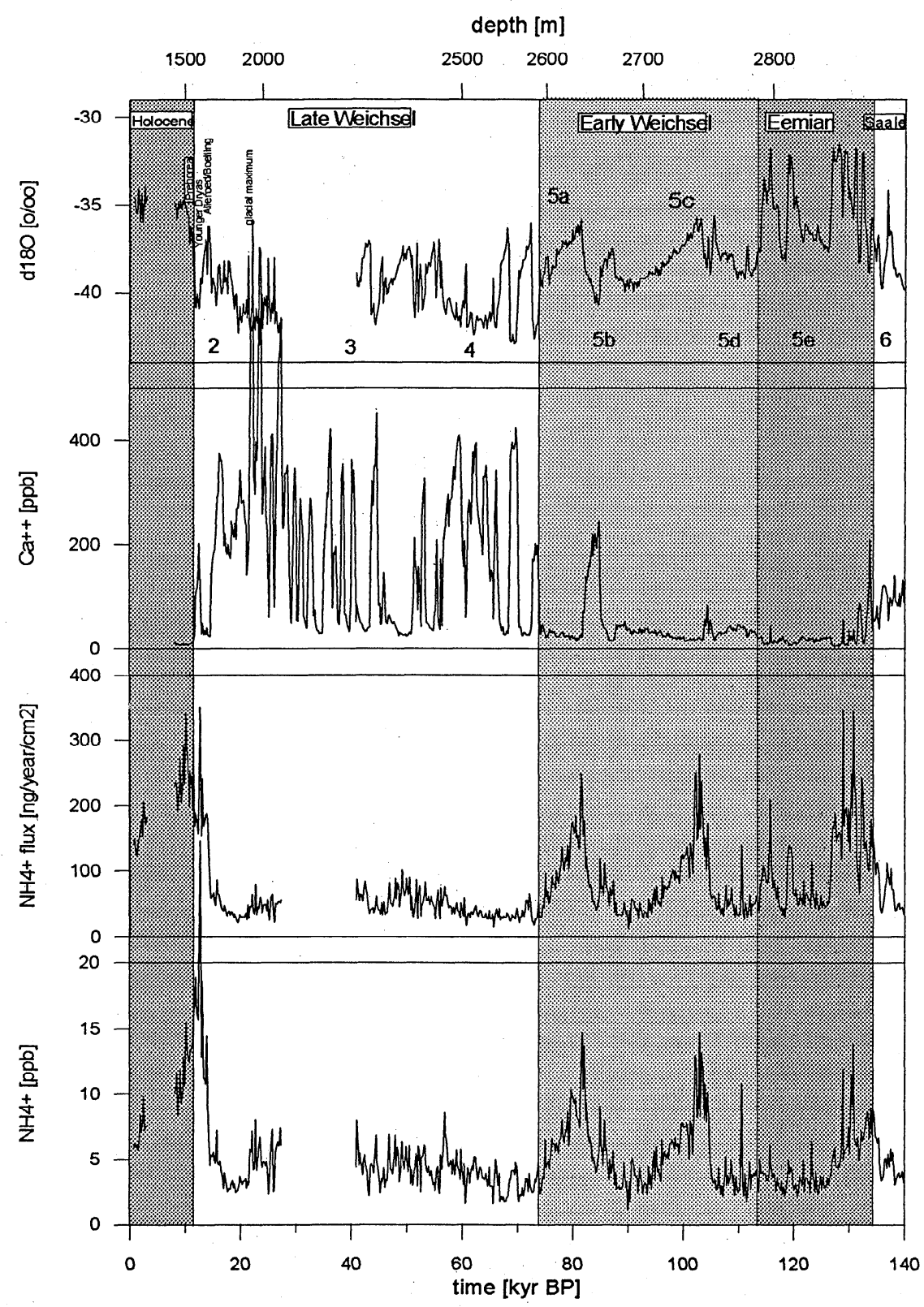

Figure 2. The 200-year means of ammonium ice concentrations and fluxes, and calcium concentration. On the top of the figure is the $\delta^{18} \mathrm{O}$ record [from Dansgaard et al., 1993] with the same resolution. Marine isotopic stages 1 to 6 are indicated. Holocene, late Weichsel, early Weichsel, Eemian, and Saale are indicated according to Dansgaard et al. [1993]. 
To which extent, however, is not yet clarified, since a parameterization of the transfer function for aerosols is missing. Variations in fluxes (concentrations times accumulation rates) instead of concentrations give insight in the direction of possible corresponding atmospheric changes. In the following discussion we will therefore consider both the concentration and the flux record in order to point out whenever the interpretation in terms of atmospheric concentrations may be affected by changing deposition and/or transport mechanisms. Postdepositional changes apart from sublimation of snow are negligible for background ammonium (see section 4.1.), since it is believed to be irreversibly deposited as $\mathrm{NH}_{4} \mathrm{HSO}_{4}$ and $\left(\mathrm{NH}_{4}\right)_{2} \mathrm{SO}_{4}$ at Summit indicated by the well-preserved atmospheric ratio of $\mathrm{NH}_{4}^{+} / \mathrm{SO}_{4}^{2-}$ in the snow [Silvente and Legrand, 1993]. In preindustrial times with low sulfate levels probably also $\mathrm{NH}_{4} \mathrm{NO}_{3}$ is formed. In this case and also in the case of high ammonium spikes (see section 4.1.) the presence of ammonia in the atmosphere over Summit may be important, which would lead to an ammonia dry deposition flux. Ammonia diffuses very quickly in the ice matrix contrary to ammonium [Schwander et al., 1987]. However, there is no indication of diffusional smoothing of the signal within the firn comparing preindustrial and recent data. Diffusion of $\mathrm{NH}_{4}^{+}$over a timescale of 10,000 years can be excluded since in high ammonium spikes, always the same correlation with formate is found (see section 4.1.). Over a longer timescale, higher-resolution ammonium data are required to address this question.

An overview of the concentration record is given in Figure 2. Fluxes are calculated by multiplying concentrations with mean accumulation rates [Dansgaard et al., 1993]. The record reveals various features in different time windows. They are discussed below in terms of possible changes related to source region, the source strength, the circulation pattern, and the deposition mechanisms of ammonium.

\section{Results and Discussion}

To discuss the ammonium ice core record, we will first try to identify the source regions. A quantitative analysis of seasonal back trajectories for Summit is not yet available. Therefore we have to rely on indirect evidences.

Schlesinger and Hartley [1992] suggested comparable emission rates from oceans as from natural soils on a global scale. However, concluding from the up to five-time lower ammonium concentrations during the Holocene found in Antarctic ice cores [Silvente and Legrand, 1993; Legrand and Delmas, 1988; Palais and Legrand, 1985], ocean sources are significantly lower than continental sources. We therefore assume that ammonium deposited on the Greenlandic ice sheet is mainly of continental origin.

The general westerly circulation of storm tracks crossing central Greenland would suggest North America
(NA) as the main source for continental species showing a turnover time comparable to that of ammonium. Furthermore, NA is the largest continental area close to Greenland. A dominating influence of moisture source in the Southwest suggested by Bolzan and Strobel [1994] for the Summit area. As long as a large part of the ammonium is wet deposited, the "water vapor air masses" have to be somehow related to the "ammonium air masses": Either ammonium and water vapor have similar source regions or a mixing of air masses occurs during the transport, which leads to precipitation of ammonium. Also, based on the calculation of 5-day back trajectories NA is suggested as the main source region of continental species for Dye 3, southern Greenland, during the summer season [Davidson et al., 1993], and a comparison of the frequency of high ammonium spikes [Whitlow et al., 1994] shows that Summit and Dye 3 are influenced by the same source region at least during the summer season. In spring, however, the situation differs from summer. Pollutants from Eurasian regions accumulate in the Arctic basin during winter, due to low precipitation [Heidam, 1984]. Subsequently, these species are transported to central Greenland following the breakup of the polar vortex in spring [Whitlow et al., 1992]. Since ammonium concentrations are usually very low in winter snow, the winter source region is of minor importance for the total ammonium deposited on the ice sheet. Source regions may have been changed along with the large changes in circulation pattern which occurred over the last climatic cycle. We can hypothesize at least for the Holocene that the principle source region for ammonium stayed unchanged: the $\delta^{18} \mathrm{O}$ record shows little variability during the Holocene [Dansgaard et al., 1993]. This suggests that there were no major shifts in storm track pattern which determine the precipitation ( and the $\delta^{18} \mathrm{O}$ ) in Greenland over at least the last 10,000 years and it is reasonable to assume that the relevant source regions and transport path remained essentially unchanged also for short-living chemical species. Although this argument does not hold for the large climate changes during glacial age, we assume for the following discussion that the general westerly circulation was still dominant, which is supported by the model simulation by $W e b b$ et al. [1993a]. We will therefore only discuss the North American continent as the source region for ammonium.

We are aware that not only a change in the source region but also changing biomes with corrsponding changes in ammonium emissions could significantly influence the long-term record. However, flux measurements above different natural ecosystems, e.g., different wood compositions, are still scarce and not well understood (see section 1).

\subsection{Record of Biomass Burning}

The high-resolution ammonium record shows a pronounced seasonal signal with very low winter values between the detection limit and $3 \mathrm{ppb}$ and one to sev- 
eral peaks during summer in the range of 5 to $15 \mathrm{ppb}$ [Silvente and Legrand, 1993; Fuhrer et al., 1993]. This feature in the ammonium record is referred to in the following as the background contribution to the ammonium deposited on the ice sheet. Superimposed on the background signal, large ammonium spikes are found, which carry a different chemical signature. They are accompanied by elevated organic acid concentrations, especially formate, originating most probably from events of biomass burning in high latitudes [Legrand et al., 1992]. In such spikes the molar $\mathrm{NH}_{4}^{+} / \mathrm{HCOO}^{-}$ratio is close to one suggesting ammonium formate as the relevant species. The strong correlation between formate and ammonium sets in for $\mathrm{NH}_{4}^{+}$levels between 15 and $25 \mathrm{ppb}$ in the Holocene [Legrand and deAngelis, this issue]. This information was used to subtract a biomass burning record from our $\mathrm{NH}_{4}^{+}$data set (Figure 3).(The data between 600 and $1300 \mathrm{~m}$ was not analyzed statistically due to the low sampling frequency in this part of the core.) Both the 15 and the $25 \mathrm{ppb}$ threshold have to be considered when discussing trends in the record, since shifts in the threshold value with time within this range cannot be distinguished based on the few available formate data points. A decreasing amount of ammonium originating from biomass burning is deposited on the ice sheet throughout the Holocene, however, it cannot be derived from the data if there is a trend in the contribution of biomass-burning ammonium to the total ammonium during this time period. The contribution of biomass-burning ammonium reaches from 10 to $40 \%$ (Figure 3 ). This is a lower estimate since we used a threshold value of 15 (or 25) ppb, implying that the background concentration is set at 15 (or 25) ppb in years with fires. Also, during the ice age, a few high ammonium spikes can be identified as biomass-burning events. However, with the layer thinning with increasing depth, the uncertainty of the threshold value increases [see Legrand and deAngelis, this issue]. A highresolution formate record would be required to derive a biomass-burning record for earlier times and to give an error estimate. Another approach to estimate the biomass-burning contribution can be made by calculating the ammonium in spikes higher than twice the standard deviation above the average (taken for $10 \mathrm{~m}$ intervals), which gives a contribution of about $25 \%$ for the Holocene part, falling within the range of the 15 and 25 threshold calculations. For earlier times this approach shows a $10 \%$ biomass-burning contribution for the early marine oxygen isotope stage (MIS) 4 and stage 2 (see Figure 2), up to $20 \%$ in MIS stages 3 , in parts of 4 , and in stage 5 , and between 10 and $15 \%$ during the Eemian. Because of the thinning of the layer and the dispersion during the measurement these values are certainly underestimated during the pre-Holocene part. Calculating a dispersion of, e.g., half a year for the Holocene part, which corresponds to the dispersion encountered in about $2000 \mathrm{~m}$ (i.e., stage 3), this leads to an underestimatation of the biomass burning contribution of



Figure 3. Ten-meter means of background ammonium (not from biomass burning) and ammonium from biomass burning compared to the total ammonium concentration in $55-\mathrm{cm}$ mean concentrations during the Holocene. The data points between 700 and $1300 \mathrm{~m}$ are mean concentrations over about $55 \mathrm{~cm}$. On the top the ratio of "biomass-burning" ammonium to background ammonium. The biomass burning and the background contribution and the ratio are calculated with 15 (thin) and $25 \mathrm{ppb}$ (dotted) treshold values (see text).

about $30 \%$ when calculating contributions higher than twice the standard deviation above the $10 \mathrm{~m}$ mean.

The mean annual area burned in Canada of about $10,000 \mathrm{~km}^{2}$ leads to $37 \mathrm{Tg}$ of burned dry matter, corre- 
sponding to $18 \mathrm{Tg} \mathrm{C}$ [Seiler and Crutzen, 1980]. With a molar $\mathrm{NH}_{3} / \mathrm{CO}_{2}$ emission ratio of $23 \times 10^{-4}$ for boreal forest fires [LeBel et al., 1991] and $89 \%$ of the carbon released as $\mathrm{CO}_{2}$ [Stocks, 1991], this leads to Canadian $\mathrm{NH}_{3}$ emissions of $0.04 \mathrm{Tg} \mathrm{N} \mathrm{yr}{ }^{-1}$. Taking the upper estimate for emissions from natural ecosystem from Lövblad et al. [1993], to be $0.5 \mathrm{ng} \mathrm{m}^{-2} \mathrm{~s}^{-1}$, an emission rate for Canada and Alaska (11.5 million $\mathrm{km}^{2}$ surface area) of $0.18 \mathrm{Tg} \mathrm{N} \mathrm{yr}{ }^{-1}$. These estimates suggest that the ratio of ammonium originating from biomass-burning to background ammonium found in the ice is comparable to the ratio of the corresponding emissions in the source region. However, the contribution of ammonium originating from biomass burning is supposed to be overproportionally represented in the ice compared to contribution in the source region, due to enhanced convection during forest fires and therefore easier access of $\mathrm{NH}_{x}$ to the free troposphere [Andreae et al., 1988] where long-range transport is more efficient. Either this mechanism is compensated by the greater availability of background ammonium, since background ammonia emissions are not limited in time and area in the way it is the case for biomass-burning ammonia, and therefore the probability of air masses containing background ammonium to reach Greenland is much larger than that of biomassburning plumes, or natural ammonia emissions are underestimated. Clearly, more $\mathrm{NH}_{3}$ flux measurements above boreal natural ecosystems are needed.

Comparison of our recent mean ammonium summer concentrations with area burned in Canada since 1920 [Stocks, 1991] shows that there are only very few time intervals when a correlation is obvious. The period with both the lowest values in ammonium concentrations and in the area burned is found in both records in the early 1960s. Years with high concentrations and large area burned are 1923, 1929, and 1961. For all of the other years with large area burned, no obvious correspondence is detected in our ice core record; for example, the documented enhanced fire activity in the 1980s is not reflected in our record. Conversely, no increased fire activity is documented neither in NA nor in Siberia in the years 1950 and 1908, when high spikes are observed in our record. (In 1908 the Tunguska event, probably a cometary impact, caused some forest burning in Siberia [Rasmussen et al., 1984]. Apparently, the extent of the forest fire was very limited since no fire scars were found in trees in Siberia (Swetnam, personal communication, 1994). Therefore the ammonium spike in 1908 is most probably not related to the Tunguska event.) However, this last case is rather rare: Figure 4 shows that $\mathrm{NH}_{4}^{+}$ summer concentrations since 1920 and the area burned in Canada are rather uncorrelated, but only few points exist in the right bottom half of the plot, indicating that for a given ammonium summer concentration a mimium fire activity is required. The lack of correlation between the $\mathrm{NH}_{4}^{+}$and the area burned clearly underlines the role of atmospheric transport for the ammonium ice concen-

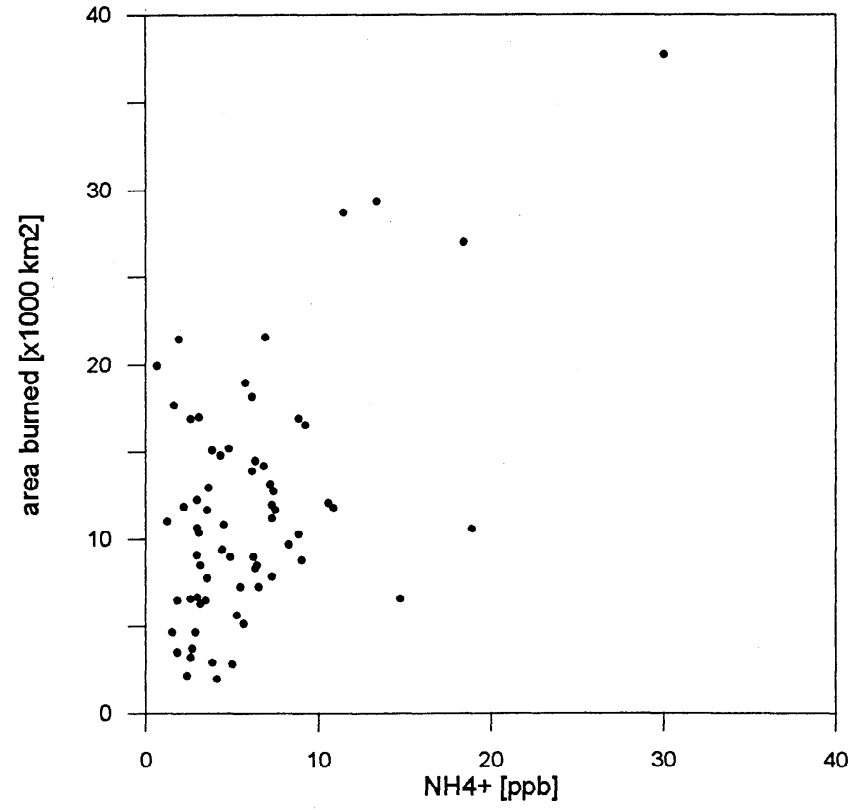

Figure 4. Correlation of the yearly area burned in Canada since 1920 and the average ammonium concentrations between spring and fall (calculated from the six summer "months" determined according to section 4.2). Three values higher than $40,000 \mathrm{~km}^{2}$ are not shown.

tration. To record an ammonium spike in the ice, it is decisive that the meteorological conditions are favorable to transport biomass-burning plumes to Greenland and deposit them there. Although it does not seem possible to extract a precise fire history from the ammonium ice record, the above estimated contribution of biomass burning to the ammonium flux in Greenland can still be statistically significant. On a long-term basis in any case the probability to detect ammonium from biomass burning in Greenland ice cores is linked to the surface area burned and to the transport. As long as the meteorological conditions do not change, the large-scale variations in the biomass-burning record from the ice sheet will be dominated by the surface area burned. As a first approach, we may use the $\delta^{18} \mathrm{O}$ ice record as a proxy for the meteorological conditions influencing Greenland. The $\delta^{18} \mathrm{O}$ signal would change with different transport path and source regions [Johnsen et al., 1989; Charles et al., 1994]. The $\delta^{18} \mathrm{O}$ ice core record suggests that the circulation pattern which determines the advection of moist air masses to Greenland has not significantly changed over at least the last 10,000 years [Dansgaard et al., 1993]. Assuming further that the $\mathrm{NH}_{4}^{+}$transfer function remained unchanged during this time period, we conclude that the ammonium ice core record reflects a decreasing fire activity in northern NA during the Holocene. This conclusion is supported by measured charcoal depositions in Canadian lake sediment records, which show a enhanced fire activity in the early to mid-Holocene compared to present for most regions in Canada [Anderson et al., 1989; Terasmae and Weeks, 
1979]. Anderson et al. [1989] also report evidence for an opening of forests and expansion of grassland from pollen records which may account for the increased fire activity .

\subsection{Last 300 Years}

As discussed above, the anthropogenic contribution to global ammonia emissions is now largely dominating the natural emissions. The anthropogenic contribution to ammonium deposition on the central Greenland ice sheet is investigated below. There are only a few ammonium data sets available from the Greenland ice sheet that cover the last 300 years, and the data suffer from bad time resolution and contamination problems [Laj et al., 1992; Whitlow et al., 1994]. The ammonium record presented by $L a j$ et al. [1992] tends to decrease over the last 100 years. Our record, however, shows no trend of the mean ammonium concentration exceeding the natural variability (Figure 1 ). The high

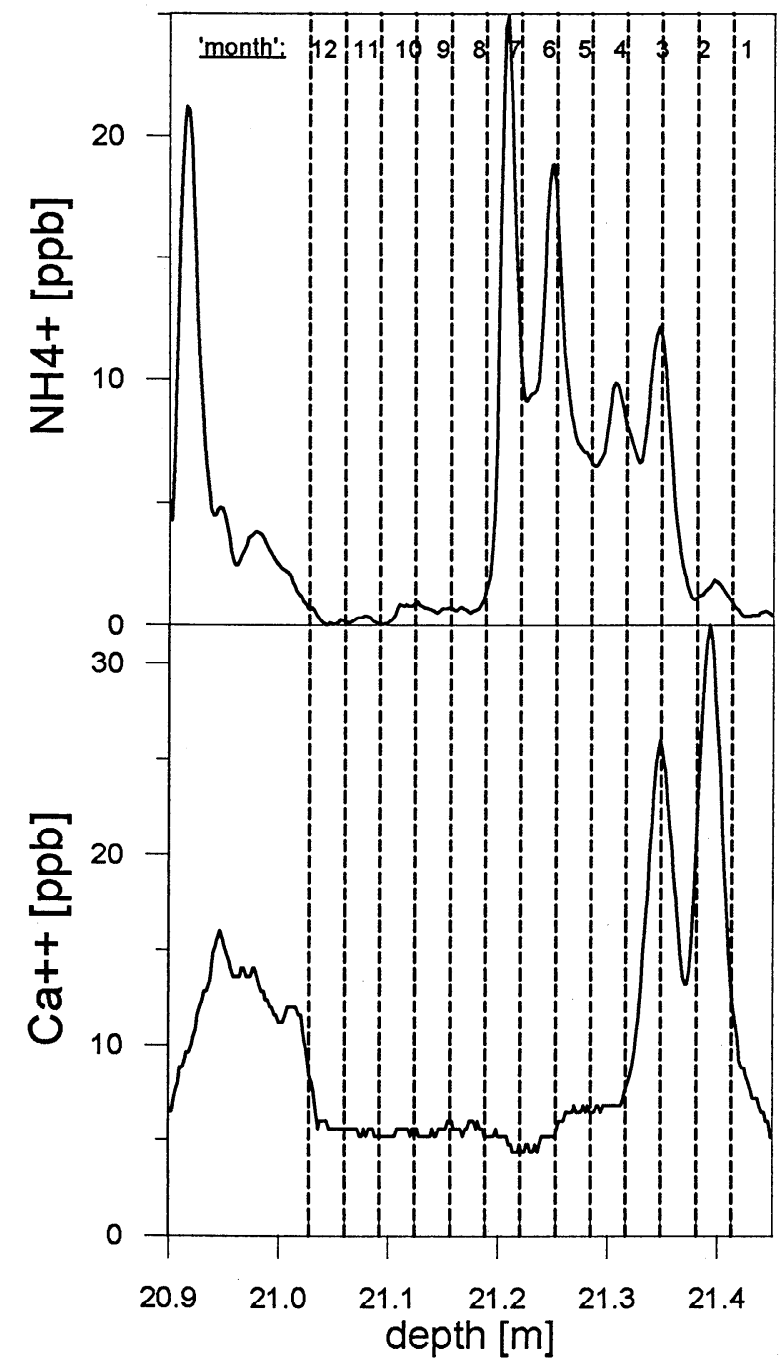

Figure 5. An example of the analysis performed over the last 300 years: The year defined by the onset of the $\mathrm{Ca}^{2+}$ springtime peak in 1942 to the onset in 1943 is divided up in 12 equidistant parts. resolution of our record allows for a more detailed analysis. We calculated an approximation of monthly ammonium concentrations by setting the increasing leg of the seasonal $\mathrm{Ca}^{2+}$ peak to "month" No 1 and dividing the so-defined year into 12 equidistant parts (Figure 5). These are not real months since they do not take into account the short-term accumulation pattern. Our $\mathrm{Ca}^{2+}$ record was established along the same sample as for $\mathrm{NH}_{4}^{+}$providing the same resolution (K. Fuhrer, unpublished data, 1995). It is generally believed that $\mathrm{Ca}^{2+}$ in Greenland ice cores has a clear seasonal signal with a pronounced spring time peak [e.g., Whitlow et al., 1992]. "Months" 12, 1, and 2 show a significant increase of the ammonium concentration by more than a factor of 2 since 1950 (Figure 6). This feature is not caused by the spikes in the record since it is also true if only background concentrations are included in the analysis. No significant trend is found during the summer season (Figure 6). We found also an increase of the mean "winter" concentrations (we define them as concentrations below $3 \mathrm{ppb}$ ) over the last 20 years. It is accompanied by a decrease of the length fraction of "winter" concentrations, which is defined as the ratio of intervals with "winter" concentrations to the total of the intervals. The spring-time increase contributes to less than $10 \%$ to the total flux, which is too small to be detected within the natural variability of the total record. The atmospheric ammonium level in middle and low latitudes has increased over the seasons due to anthropogenic pollution [Irving, 1990; Langford et al., 1992]. In contrast, major contributions from natural sources only occur during summer (see section 1). We therefore suggest that the recent ammonium increase in our record in spring together with the increase of the concentrations lower than $3 \mathrm{ppb}$, which affects mostly the winter half year, are of anthropogenic origin. As discussed above, a major input of polluted air mass in spring has also been observed for other continental species. Asman et al. [1988] estimated a doubling of European ammonia emissions since 1920 based on livestock statistics and they considered contributions of natural emissions to be already negligible in Europe by 1900. Since no trend in spring-time ammonium concentration is observed in ice between 1660 and 1950, when presumably livestock has increased in phase with population, we conclude that ammonium deposited in spring on the ice sheet before 1950 does not originate substantially from anthropogenic sources. The following mechanism can possibly account for the observed spring-time ammonium increase in ice since 1950: The characteristical travel distance for $\mathrm{NH}_{x}$ increases with elevated $\mathrm{SO}_{2}$ and $\mathrm{NO}_{x}$ emissions, due to a more efficient conversion of ammonia into the aerosol phase [Hov and Hjollo, 1994], which experiences a longer atmospheric lifetime than $\mathrm{NH}_{3}$. In support of this hypothesis, $\mathrm{SO}_{2}$ emissions have increased rapidly since 1950 in Eurasia [Mylona, 1993] and a strong increase in acidity is also observed in ice cores from central Greenland after 1950 


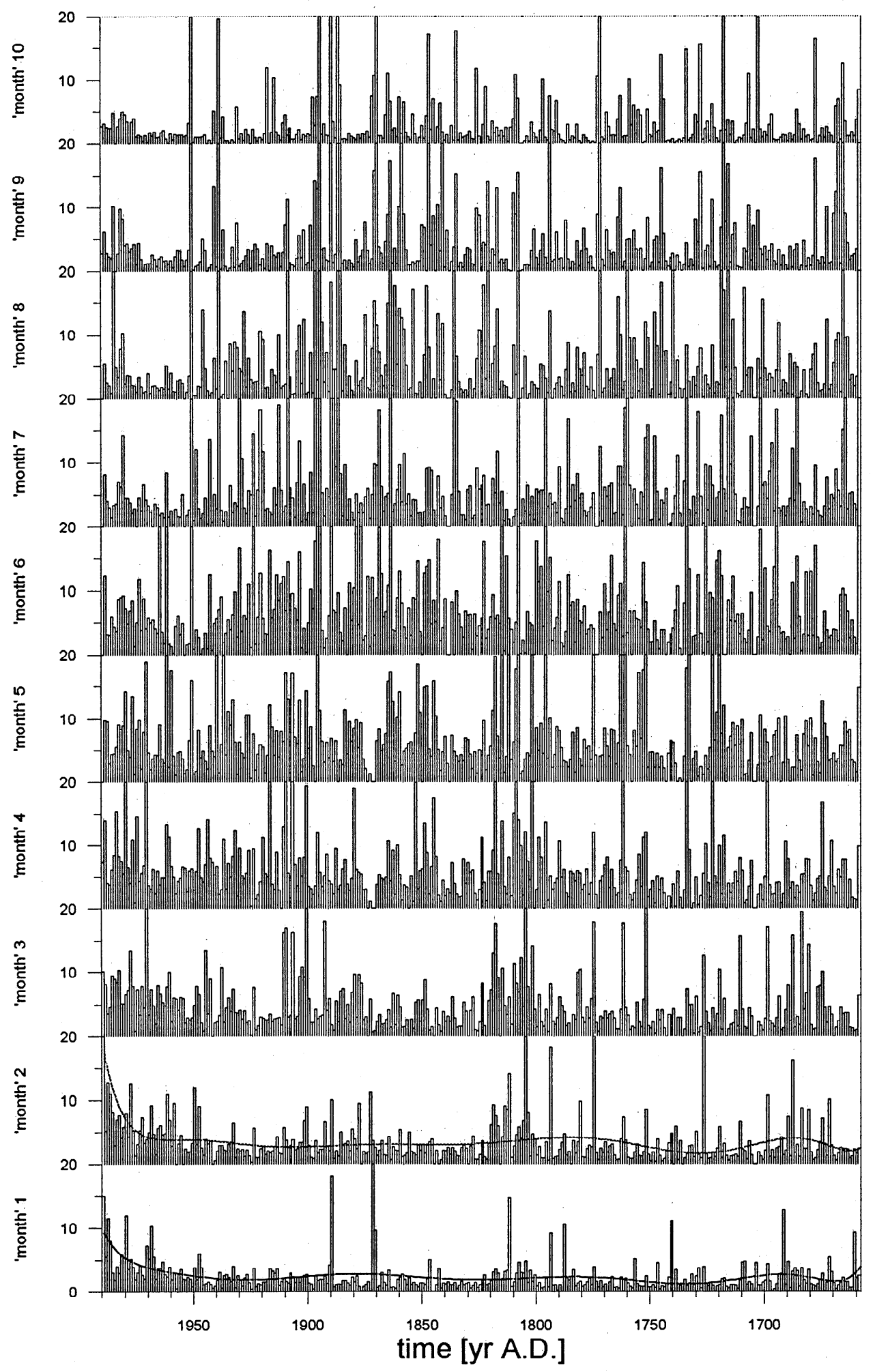

Figure 6. "Monthly" ammonium concentrations in parts per billion over the last 300 years. Zero values indicate gaps in the record during the corresponding "month" (see section 4.2). All graphs are clipped at the y axis. Polynomial trend lines are added in for months 1 and 2 to point out the recent springtime increase.

[e.g., Legrand and deAngelis, this issue; Mayewski et al., 1993].

As discussed above, a shift in the ammonium source region influencing Greenland from Eurasia via the Arctic basin to subarctic and Arctic North America occurs from spring to summer. In summer, no ammonium increase is observed on the ice sheet (see Figure 6). In the following we will discuss how a missing anthropogenic $\mathrm{NH}_{x}$ source in summer can be explained and second, why $\mathrm{SO}_{2}$ - and $\mathrm{NO}_{x}$-enhanced long-range transport of 
$\mathrm{NH}_{x}$ as suggested by Hov and Hjollo [1994] does not occur in summer. A weaker atmospheric circulation in summer could account for preventing long-range transport of anthropogenic $\mathrm{NH}_{x}$ to Greenland. Air masses of more local origin in summer were calculated for Dye 3, southern Greenland [Davidson et al., 1993], and it was shown that at least in summer, Dye 3 and Summit have the same source region [Whitlow et al., 1994]. Further, an ammonium increase in summer in the order of magnitude of the spring-time increase could be masked by the large variability of summer concentrations and the higher mean concentrations in summer (Figure 6), due to natural sources being at their maximum. Even if no anthropogenic ammonium reaches the NA Arctic in summer, one might expect a prolongation of the lifetime of $\mathrm{NH}_{x}$ in case of increased $\mathrm{SO}_{2}$ and $\mathrm{NO}_{x}$ emissions also in summer. This effect could cause an even more pronounced absolute ammonium increase in summer than in spring, considering the higher ammonium summer concentrations. A comparison of recent sulfate data [Silvente and Legrand, 1993] with data from 1900 [Steffensen, 1988] confirms that summer snow layers show an anthropogenic increase of sulfate (a factor of 2 compared to a factor of 3-4 in spring). Also, the anthropogenic nitrate increase in polar ice [Neftel et al., 1985; Mayewski et al., 1986] is due to an increase of summer concentrations [Whitlow et al., 1992]. We suggest two explanations for the apparently missing more efficient conversion of $\mathrm{NH}_{3}$ in summer: 1 . The observed anthropogenic $\mathrm{NO}_{3}^{-}$and $\mathrm{SO}_{4}^{2-}$ increases in summer snow do possibly not reflect an increase of $\mathrm{NO}_{x}$ and $\mathrm{SO}_{2}$ emissions in the ammonium source region; that is, these species do not arrive along the same transport path as $\mathrm{NH}_{x}$. In fact, besides some sporadical input of contaminated air plumes, aerosol data presented by Talbot et al. [1993] could not definitely confirm an influence of anthropogenic $\mathrm{SO}_{2}$ and $\mathrm{NO}_{x}$ emissions to the NA Arctic. 2. The molar ratio of $\mathrm{NH}_{4}^{+}$to $\mathrm{SO}_{4}^{2-}$ in boreal natural ecosystems is probably much smaller than at agricultural sites. Ratios lower than 2 are measured in the NA boundary layer and troposphere [Talbot et al., 1993], indicating a complete neutralization of $\mathrm{NH}_{3}$. If the ratio of $\mathrm{NH}_{4}^{+}$to the sum of $\mathrm{SO}_{4}^{2-}$ and $\mathrm{NO}_{3}^{-}$has been low also for the preindustrial environment, enhanced $\mathrm{SO}_{2}$ and $\mathrm{NO}_{x}$ emissions would probably not affect the transport distance of $\mathrm{NH}_{x}$ in a drastic way. (Even if also in Europe the $\mathrm{SO}_{2}$ and $\mathrm{NO}_{x}$ emissions could have completely neutralized the $\mathrm{NH}_{3}$ emissions already in 1880 [Asman et al., 1988; Mylona, 1993], the distribution of the sources allowed for a locally unneutralized atmosphere and increasing $\mathrm{SO}_{2}$ and $\mathrm{NO}_{x}$ emissions could still enhance the transport distance of $\mathrm{NH}_{x}$.) We conclude that during summer, contributions of anthropogenic ammonia to the NA Arctic troposphere are not significant compared to natural ammonia emissions, and the mechanism proposed by Hov and Hjollo [1994] is not important in the discussed region.
This would confirm the dominance of a remote northern NA source region for the ammonium deposited in central Greenland, since nowadays anthropogenic ammonia emissions largely dominate natural ones in the United States [Langford et al., 1992]. Several authors suggest that emissions from boreal forest and tundra are negligible and compensation points close to zero [Lövblad et al., 1993; Schlesinger and Hartley, 1992]; that is, boreal ecosystems should act as a sink for ammonia. This would imply that northern NA is not a source for ammonia apart from biomass burning. The above conclusion that background ammonium deposited on the central Greenland ice sheet in summer originates from biogenic emissions from undisturbed ecosystems in northern NA is in clear contradiction with the existing emission estimates for natural ecosystems. Transport models and trajectory analysis will have to be applied for the discussed regions to understand the recent ammonium ice core record in a more quantitative way.

\subsection{Ice Age-Holocene Transition and the Holocene}

At 14,500 years B.P. the Alleroed Boelling (AB), a warm stage lasting about 2500 years [Johnsen et al., 1992], marks the beginning of the transition from the ice age into the present interglacial. The ammonium concentration already starts to increase slightly before 16,000 years B.P. from very low values in glacial age (Figure 2) and increases steadily throughout $\mathrm{AB}$ (Figure 7a). It reaches the highest concentrations of the whole record in the Younger Dryas (YD), a cold event of about 1000 years duration, detected mainly in European lake sediments, Arctic ice cores, and Atlantic Ocean sediments [e.g., Eicher and Siegenthaler, 1976; Johnsen et al., 1992; Fairbanks, 1989]. In spite of the climatic warming after 17,000 B.P. the Laurentide ice sheet covered still almost the same land area at 14,500 years B.P. as at its maximum extent, reaching down to $40^{\circ} \mathrm{N}$ in eastern North America and to $50^{\circ} \mathrm{N}$ in the west, and only had started to retreat slightly from the southwest [Mayewski et al., 1981]. At 10,000 years B.P. the ice sheet had withdrawn to the Northeast but covered still the whole Hudson Bay area down to Lake Michigan in the south and along the Great Lakes with the western margin. The Hudson Bay and the land area northeast from it remained covered until 8000 years B.P. At 6000 year B.P. finally the Laurentide ice sheet had disappeared. We suggest that the ammonium record parallels the buildup of biomass with the ameliorating climate toward the the end of the last glaciation and during AB. Since the major retreat of the ice sheet occurred from the south west, and almost the entire Canada was still ice covered at the beginning of the deglaciation, the large increase in ammonium in $\mathrm{AB}$ is most probably produced by build up of biomass in the United States, initiated by a temperature increase, later on in western Canada. Additionally, with the retreat of the 

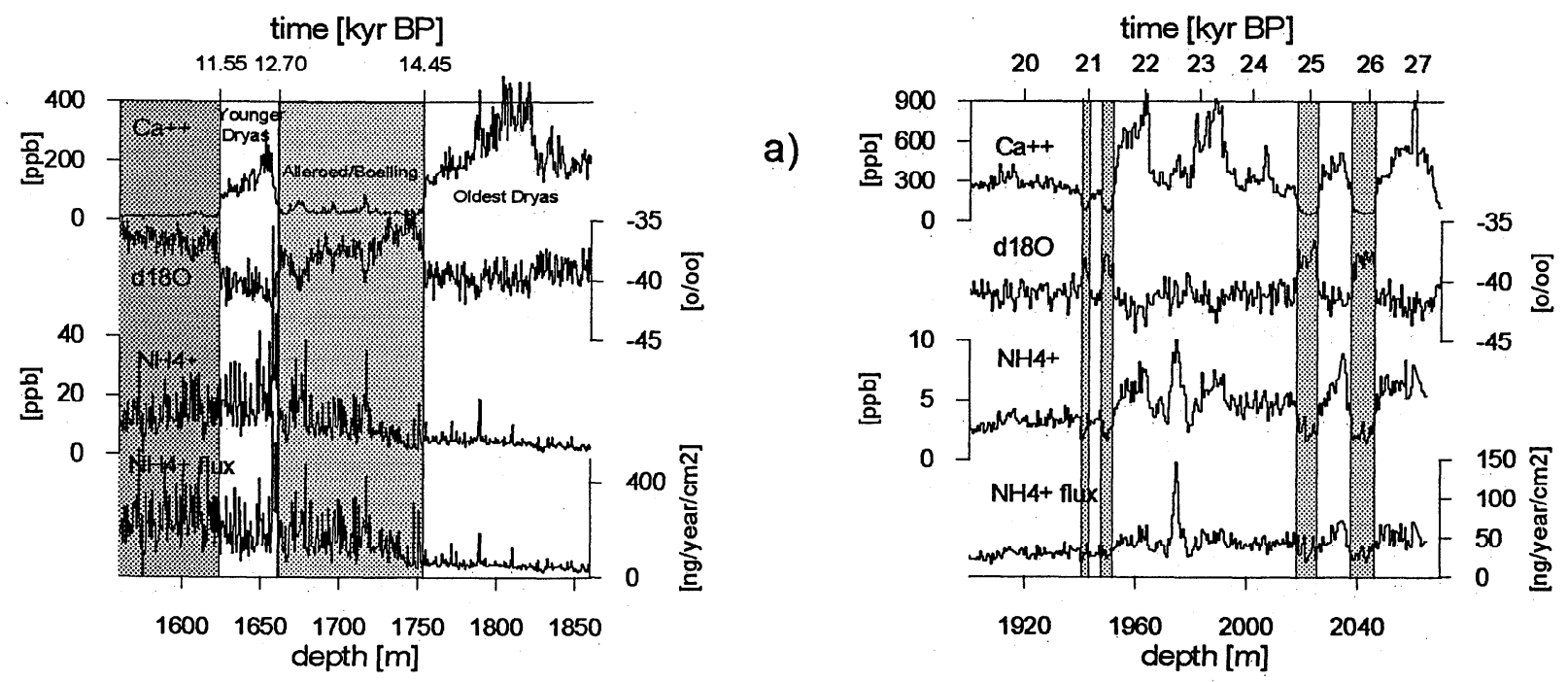

b)
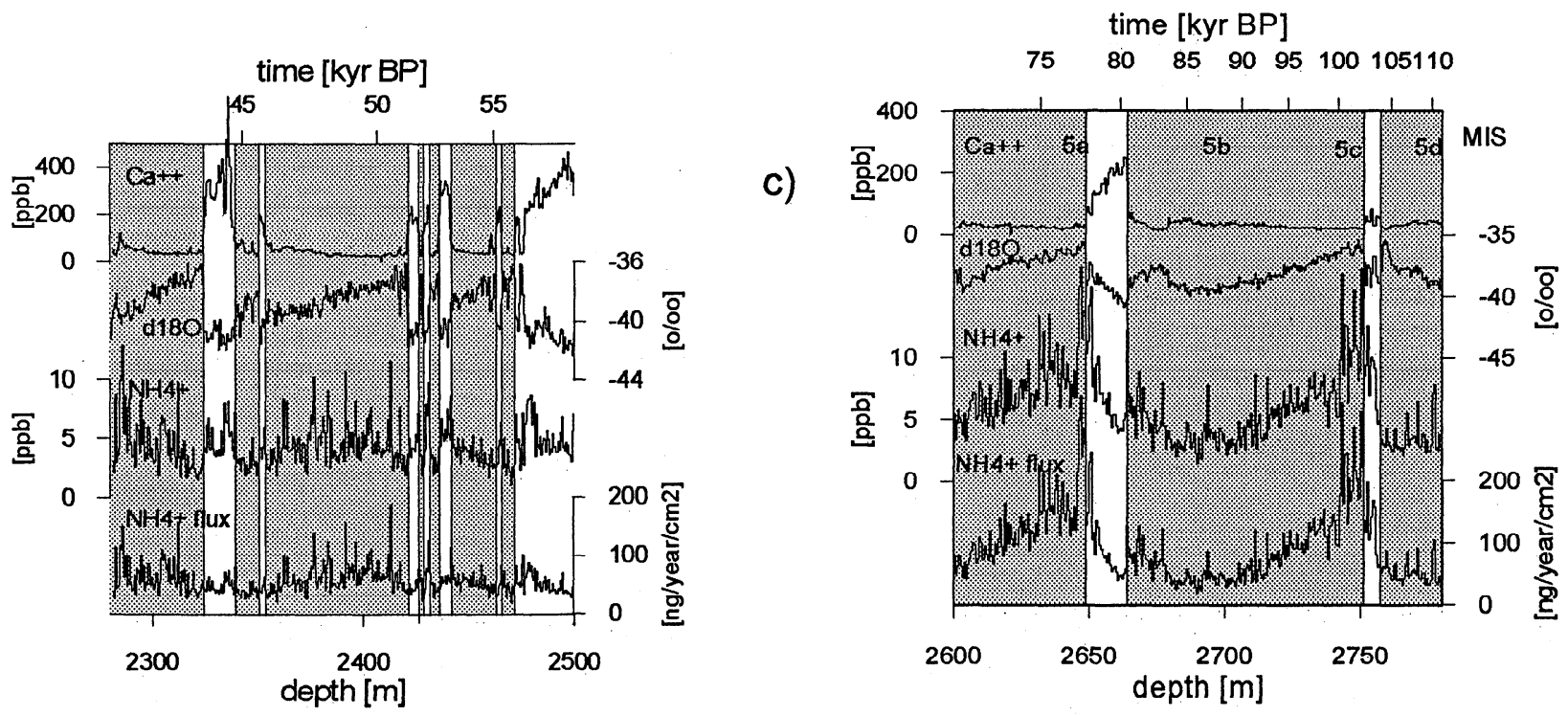

Figure 7. Comparison of $\mathrm{Ca}^{2+}, \delta^{18} \mathrm{O}, \mathrm{NH}_{4}^{+}$, and $\mathrm{NH}_{4}^{+}$flux records for different stages: (a) the transition into the present interglacial, (b) a sequence around the glacial maximum, (c) a sequence from the first part of the late Weichsel, (d) the early Weichsel.

ice sheet, plant material was released [Franzen, 1994], which was preserved and not outwashed or decomposed under the glacier, representing an ammonium source due to decomposition and possibly biomass burning. The high ammonium concentration found in YD may be partly due to changes in deposition and transport mechanisms caused by the twofold lower accumulation rate compared to that in $\mathrm{AB}$ [Alley et al., 1993] and the colder climate, as discussed in section 3 . We cannot quantify these effects, but they will certainly not explain the high YD concentrations compared to glacial concentrations. All species which are not of continental biogenic origin go back to glacial conditions during YD, [e.g., Mayewski et al., 1993]. We can conclude that general circulation patterns determining the transport to Greenland and the scavenging mechanisms over the ice sheet in YD are comparable to those in glacial times.
The different behavior of ammonium in YD compared to glacial times is thus most likely explained by a change in source strength of ammonium. In fact, there is no evidence for a cold YD event neither in the United States nor in western Canada. There is no firm evidence that the retreat of the Laurentide ice sheet drastically slowed down between 11,500 and 10,500 years B.P [Mayewski et al., 1981], and no decrease of temperature is recorded on the NA continent where pollen profiles indicate gradual changes in vegetation cover toward a warmer climate [Ritchie and Harrison, 1993; Webb et al., 1993b]. We therefore suggest that the continental biomass pool generating the ammonium deposited in Greenland was not decreased in YD. The high ammonium concentration found in YD is then explained by an unchanged or gradually increasing source strength compared to $A B$, located south from the ice sheet in $40-50^{\circ} \mathrm{N}$ and along 
the retreating Laurentide ice sheet to the Northwest, in combination with changes in deposition mechanism and transport, which are normally encountered with a colder climate, due to lower accumulation rate and probably higher wind speed.

The most prominent feature in the Holocene ammonium record is the decreasing trend of average concentrations from more than $20 \mathrm{ppb}$ in YD, to less than 6 $\mathrm{ppb}$ in present times, as shown in Figures 2 and 3. This trend is most pronounced in the early Holocene up to 8000 years B.P. The few data points measured between 600 and $1300 \mathrm{~m}$ (3000- 8000 years B.P.) indicate a drop in the general trend; however, it is possible that the sample selection is not representative. The length fraction of intervals with "winter" concentrations is up to 5 times higher than contribution of "winter" concentrations to the total ammonium deposited. Since only 30 $m$ were analyzed in a noncontinuous way in this interval, these data should be interpreted cautiously, and we exclude them from the following discussion. During the preboreal up to 8000 years B.P. and between 3000 years B.P. and present time the general decrease in average concentration is induced by a decrease of both, biomassburning and background ammonium (Figure 3). In parallel to the decrease of background concentrations an increase of the length fraction of "winter" concentration (below $3 \mathrm{ppb}$ ) is also observed. Other short-lived chemical species of continental biogenic origin do not show the same behavior during the Holocene (We exclude biogenic species with very different turnover times like methane from our considerations, since their source area may be very different from ammonium). Background formate (for which biomass burning contributions are subtracted) shows an increasing trend from the beginning of the Holocene up to 6000 years B.P., then it decreases slightly toward present. Background acetate starts to increase at around 9000 years B.P from low glacial values [Legrand and deAngelis, 1995]. The explanation proposed by Legrand and deAngelis [1995] is based on the extention of the Laurentide ice sheet, which persists until 6000 years B.P. in the Northeast of NA and thus prevents the apparently shorter-living acetate from reaching Greenland, whereas formate increases in phase with the buildup of boreal forests. Nitrate has, among other sources, also a potential biogenic source connected to the $\mathrm{NO}_{x}$ emissions from soils [Wolff, 1995]. The high-resolution nitrate record from Summit is not yet available and the ice core records from Dye 3, southern Greenland, and Camp Century, northern Greenland, show a large scatter throughout the Holocene [Herron, 1982] The fact that our ammonium record does not show the same development as the mentioned biogenic species suggests a different explanation for the temporal pattern of ammonium during the Holocene. In the beginning of the Holocene, during the retreat of the Laurentide ice sheet and the adaptation of the biomass to the warmer climate, NA went through a drastic change in vegetation pattern $[\mathrm{Webb}$ et al., 1993a, b; Ritchie and Harrison, 1993], producing a large amount of plant material. Together with the release of dead plant material with the continuous retreat of the ice sheet, abundant fuel for biomass burning was available as well as a potential ammonium source due to decomposition of plant material. To the current knowledge during decomposition of plants, organic acids are not emitted in significant amounts, however, the sources of organic acids are not yet well quantified [Talbot et al., 1993]. We suggest that the different temporal pattern of background organic acids and ammonium may be due to a low source strength for organics, whereas an abundant ammonia source was available from the beginning of the Holocene. If this is not the case, a large discrepancy in atmospheric lifetimes between these species is implied. The fact that ammonium reaches the highest Holocene values with a source only in the western part of the NA continent whereas formate and especially acetate only show highest values when the ice sheet retreated completely in the East would imply an atmospheric lifetime for ammonium which is much higher than the one for organic acids. The decreasing ammonium trend in the beginning of the Holocene indeed shows that the approach of the source region to Greenland with the retreat of the Laurentide ice sheet to the Northeast of NA does not affect or at least not dominate the amount of ammonium deposited in Greenland. It suggests that the lifetime of $\mathrm{NH}_{4}^{+}$is enhanced over the ice sheet, which is possible due to little precipitation over the ice sheet and wet deposition being the main removing mechanism for $\mathrm{NH}_{4}^{+}$. However, also the lifetime of organic acids should be enhanced by the same effect since they have also a high water solubility and are mainly wet deposited over the ice sheet. A large difference in lifetime seems therefore not very likely to explain the different trends of organics and ammonium in the early Holocene. Additional parameters are needed to explain the decreasing trend in ammonium toward present time. Today, a main factor influencing natural ammonia emission is the temperature [Langford et al., 1992]. Langford et al. [1992] estimate a doubling of the ammonia vapor pressure with a temperature increase of $5^{\circ} \mathrm{C}$. Temperature records derived from pollen records show an increasing trend in eastern NA with the retreat of the ice sheet up to 9000 years B.P., when modern values are almost reached [Webb et al., 1993b]. Only small and locally very limited positive temperature anomalies are observed in western United States [Thompson et al., 1993]. However, in western Canada a climate of up to $5^{\circ} \mathrm{C}$ warmer than present time developed during the retreat of the ice sheet up to 6000 years B.P., most probably due to increased solar radiation, as well as in Alaska, with summer temperatures of more than $2^{\circ} \mathrm{C}$ higher than at present time [Anderson and Brubaker, 1993; Ritchie, 1984; Ritchie and Harrison, 1993], with a temperature maximum at about 9000 years B.P. The pollen-derived temperature record is confirmed by the melt layer frequency and the $\delta^{18} \mathrm{O}$ 
record of a Canadian high Arctic ice core [Koerner and Fisher, 1990]. Both climatic proxy parameters are decreasing througout the Holocene. We propose that the decreasing trend in our ammonium background record since 9000 years is caused by a decrease in temperature in the source area, i.e., in Canada and Alaska. It is possible that the background concentrations in the early to mid-Holocene were additionally enhanced due to the shift in vegetation cover, i.e., higher ammonia emissions over grasslands than over forests [Langford et al., 1992]. As pointed out already, more research is needed here to quantify ammonia emissions over different natural ecosystems. Lake levels in eastern North America and southern Canada indicate that aridity was greatest between 9000 and 5000 B.P. [Webb et al., 1993b; Ritchie and Harrison, 1993]. Increasing wetness and decreasing temperatures toward present time would also suppress fire activity as well as ammonia emission from soils, which would support the decreasing trend in biomass burning activity recorded in the ice core and would also contribute to the decreasing trend in ammonium background concentrations. A further cause for higher fire activity in the early Holocene may be land clearing by man, as indicated by large extinction waves of animals during this time period [Martin, 1990]. Another rcason for the decreasing trend in the early Holocenc ammonium record may be the weakening of the anticyclone above the diminishing Laurentide ice sheet [Cooperative Holocene Mapping Project (COHMAP) members, 1988]. The stromtrack pattern as caused by the strong anticyclone could be favorable of transporting ammonium to central Greenland. However, if this strong ammonium decrease is just an effect of changing transport pathways and transport efficiency, one would expect this to affect also the transport of other species, which is not supported so far. The climate evolution in Eurasia proposed by Peterson [1993] and Huntley and Prentice [1993] does not show trends compatible with our ammonium record. This supports our hypothesis that NA is the main source region for ammonium deposited in central Greenland. The expanding of the winter season as indicated by the increasing length fraction of "winter" concentrations toward present time, is supported by model results calculating an enhancement of winter warming in the early to middle Holocene in high latitudes compared to present time, at least west from the Laurentide ice sheet [Mitchell et al., 1988]. An increase in length of the growing season in the early Holocene compared to present time is also derived from Canadian pollen record by Ritchie [1984]. Of course, an expansion of depth intervals with ammonium winter concentrations can also result from a change in accumulation pattern on the ice sheet, i.e., by more precipitation events occurring in the winter season. To discriminate between the two reasons, we would need high-resolution data from chemical species with different source regions than that of ammonium. As already observed for the $\mathrm{YD}$, the above interpretation of the Holocene record shows that the $\delta^{18} \mathrm{O}$ ice core record does not necessarily reflect the climate history of the NA continent.

\subsection{Glacial Age, the Last Interglacial}

The glacial $\delta^{18} \mathrm{O}$ record of the GRIP core is characterized by many sharp switches between cold and warm stages [Johnsen et al., 1992], which are also reflected in the record of most of the chemical species Mayewski et al. [1994]. Ammonium, however, does not follow this simple picture of a two-stage climate.

Ammonium is one of the few species, with nitrate and organic acids [ Herron, 1982; Legrand and deAngelis, 1995, this issue] which drop to very low values in Greenlandic ice from glacial times. For ammonium, we suppose for all the further discussion that scavenging mechanisms during the transport in the more alkaline atmosphere in glacial times (as suggested by the high $\mathrm{Ca}^{2+}$ content, which is likely to be to a large part $\mathrm{CaCO}_{3}[$ Mayewski et al., 1994] ) stayed unchanged as far as the uptake in cloud water is concerned: the $p \mathrm{H}$ of cloud water hardly exceeded 6 due to the buffering capacity of $\mathrm{CO}_{2}$, and the $p \mathrm{Ka}$ value of ammonia is 9 . However, a change in uptake into cloud water cannot be excluded for nitrate and formate [Wolff, 1995; Legrand and deAngelis, this issue]. The mean ammonium concentration is up 5 times lower during glacial maximum compared to the preboreal (Figure 2), or half of that in present conditions. We point out that this change in ice concentration is more pronounced if expressed in fluxes and probably also in terms of atmospheric concentrations, since aerosol concentrations in ice tend to increase in colder climates. Such low concentrations are reached several times along the glacial age, in 20,000, 70,000 , and 90,000 years B.P., lasting each time for several thousand years, as well as in the second half of the Eemian between 120,000 and 105,000 years B.P.(Figure 2) and before the last interglacial, at around 140,000 years B.P. The very low ammonium concentrations between 18,000 and 21,000 years B.P. (Figure 2) coincide with the time of the maximum extent of the Laurentide ice sheet [Hughes et al., 1981; Bard et al., 1993]. We conclude that they are due to the extensive glaciation of the NA continent and therefore reduced biogenic activity.

Between 28,000 and 20,000 years B.P., around the time of the glacial maximum (Figure 2), only short warm stages interrupt the cold climate. The $\mathrm{NH}_{4}^{+}$concentration drops in phase with the transition into the warm stages (Figure 7b). It is reasonable to assume that this decrease by a factor 2 is caused by changes in transport and deposition mechanisms mainly, since an enhanced or triggered biomass activity in a cold stage is not expected. We assume sharp increases of the ammonium concentrations not to reflect the development of the biomass, as supported by the slow and steady increase observed during $\mathrm{AB}$. Even the ammonium flux still shows higher values for cold climate, lower values for warm climate, indicating probably strongly in- 
creased deposition efficiency during the cold period or a shift in the source region and/or in source strength. A shift from source regions south of the ice sheets to totally ice covered regions associated with the change from cold to warm stages could account for this observation. Mayewski et al. [1994] also suggest weaker north-south circulation and a northward moving polar front during warm stages in order to explain the lower loads of mainly crustal and sea-salt species at that time. The hypothesis that variations of the $\mathrm{NH}_{4}^{+}$concentration are mainly transport driven during this time period is further supported by the rather good correlation between $\mathrm{Ca}^{2+}$ and $\mathrm{NH}_{4}^{+}$for 55 -cm mean concentrations in the interval 1800 to $2060 \mathrm{~m}$ (Figure 8). $\mathrm{Ca}^{2+}$ variations are believed to be caused to a large extent by the intensity and size of the circulation system producing the background atmosphere over Greenland [Mayewski et al., 1994]. However, some few events within the same time period show that this correlation can break up as indicated in Figure 8. A sharp ammonium increase is observed along an interval of $2 \mathrm{~m}$ at 1975.6-m depth, corresponding to a time interval of about 100 years at about 22,500 B.P., whereas the $\mathrm{Ca}^{2+}$ concentration increases only slightly (Figure $7 \mathrm{~b}$ ), leaving the $\delta^{18} \mathrm{O}$ essentially unchanged (Figure $7 \mathrm{~b}$ ). It cannot be decided if this is due to a change in transport pathways or a fluctuation in source strength. There is no indication of an ameliorated climate in pollen records, but their temporal resolution is probably not suited to detect such short events.

During the first part of the late Weichsel (Figure 2), when a generally still warm climate is interrupted by

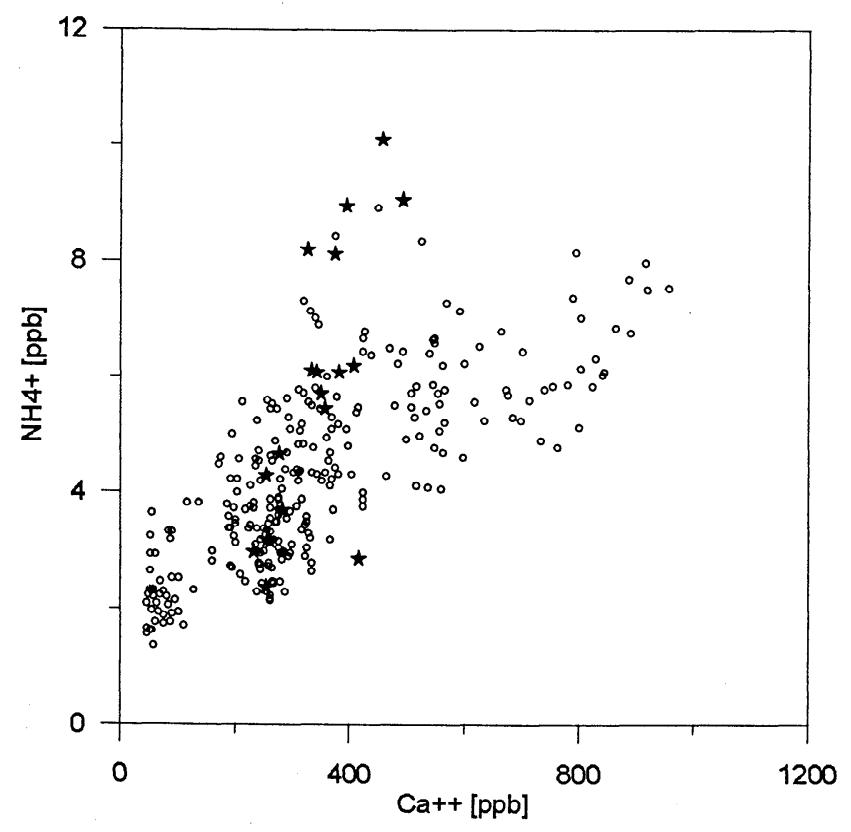

Figure 8. Fifty-five-centimeter $\mathrm{NH}_{4}^{+}$mean concentration against $\mathrm{Ca}^{2+}$ mean concentration from the interval between 1900 and $2060 \mathrm{~m}$. Stars indicate the $\mathrm{NH}_{4}^{+}$ bump in 1970-to 80-m depth (Figure 7b). shorter cold stages, the $\mathrm{NH}_{4}^{+}$concentration shows different features (Figure 7c). There are increasing trends during longer-lasting warm stages over several thousand years, reaching sometimes more than $5 \mathrm{ppb}$, i.e., present Holocene values. Cold stages seem to reset the ammonium concentration to very low values again. Transitions into cold stages still show a slight increase in ammonium concentration, reflecting again changes in deposition and transport mechanisms, as suggested for the time around the glacial maximum. Since during the warm stages a correlation with $\mathrm{Ca}^{2+}$ is no more apparent, we suggest that ammonium reflects here fluctuations in the biomass activity. Since the biomass activity on the NA continent was strongly coupled to the extent of the ice sheet, the long-term changes in ammonium concentration could also represent fluctuations in the surface covered by the ice sheet.

The marine isotopic stages $5 \mathrm{a}-5 \mathrm{~d}$ were identified between 72,000 and 112,000 years B.P. [Dansgaard et al., 1993], indicated in Figure 2 along the early Weichsel. The beginning of the cold stages $5 \mathrm{~b}$ and $5 \mathrm{~d}$ are anounced by the decreasing $\delta^{18} \mathrm{O}$ signal, but they are not separated clearly from the warm stages $5 \mathrm{a}$ and $5 \mathrm{c}$ (Figure 7d). Ammonium shows very low concentrations in stage $5 \mathrm{~d}$ and between 90 and $95 \mathrm{kyr}$ B.P. in stage $5 \mathrm{~b}$. It increases rapidly during the two short cold stages indicated in Figure $7 \mathrm{~d}$ and stays high within the transition into the following warm stages. Afterward it parallels the decreasing trend of the $\delta^{18} \mathrm{O}$ signal. We point out that contrary to the late Weichsel, the transition into warm stages does not cause a drop in the ammonium concentration but a slight increase, which is even more pronounced in terms of fluxes (Figure 7d) and probably in atmospheric concentration. Also contrary to the late Weichsel, the transition into the short cold stage at around 81 kyr B.P. shows a drop in the ammonium concentration. A similar picture with high ammonium concentrations in stages $5 \mathrm{a}$ and $5 \mathrm{c}$ was also found in the Renland core in western Greenland [Hansson, 1993]. We conclude that the increase throughout the short cold stages in Figure $7 d$ indicates an increase of the biomass activity since high concentrations are observed in the following warm stage. This phenomenon was already observed for YD, but whereas the increased biomass activity there was initiated by a warm stage, the $A B$, here the $\delta^{18} \mathrm{O}$ cold stages seem to trigger the onset of a warm period on the continent. We suggest that changes in source strength dominate the ammonium ice concentration during this time period.

The ice between $2790 \mathrm{~m}$ and $2880 \mathrm{~m}$ is thought to represent ice from the last interglacial [Greenland Ice Core Project (GRIP) members, 1993]. It is characterized by very high $\delta^{18} \mathrm{O}$ values, indicating a warmer climate than in the Holocene. Though the order of the chronology of the lower part of the GRIP core was questioned by the results from the GISPII core [Grootes et al., 1993], this affects mostly the sharp cold events during the Eemian. It is still very probable that the high $\delta 180$ 
ice is Eemian ice. It is also the only time in the whole record with $\mathrm{Ca}^{2+}$ concentrations being as low as during the Holocene (Figure 2). $\mathrm{NH}_{4}^{+}$shows concentrations which are lower than the mean Holocene level. Especially in the second half of the Eemian, the ammonium concentrations hardly exceed ice age maximum concentrations (Figure 2). Evcn fluxes reach values comparable to those during the Holocene only during the first half of the Eemian. The strong temperature correlation found for ammonium emissions from soils would lead to higher ammonium emissions during the Eemian since temperatures of more than $6^{\circ}$ higher than present in NA are suggested [Frenzel et al., 1992]. The same authors conclude also that moisture was enhanced during the last interglacial everywhere north from 600 degrees latitude and along the coast regions in NA. It is possible that more efficient scavenging during the transport in combination with more ammonia retained in the soils lead to the observed concentrations. Again we point out that also a change in the efficiency of $\mathrm{N}$ cycling in the source region depending on the type of vegetation could lead to different ammonia emissions. The variability of the $\mathrm{N}$ consumption in different biomes is, however, badly investigated.

To summarize, we find that our glacial ammonium record reflects the biomass activity on the NA continent. Several strong fluctuations occur during the last 120,000 years, which are not always in correlation with the warm stages indicated by $\delta^{18} \mathrm{O}$. Different authors suggested that the Laurentide ice sheet was built up immediately after the last interglacial, i.e. already in stages 5d to 5a [Andrews et al., 1983; Boulton and Clark, 1990; Vincent and Prest, 1987]. However, the subject is not conclusive since these dates lay far beyond the capacities of radio carbon dating. The presented ammonium record supports an early buildup of the Laurentide ice sheet since the ammonium concentration drops down to very low concentrations comparable to those during the glacial maximum already in stage $5 \mathrm{~d}$. There is no indication that such low ammonium values occur without an extensive glaciation of the NA continent, since cold climates tend to enhance the ammonium concentration due to more efficient deposition and transport. During stages 5a to $5 \mathrm{~d}$ a biomass activity comparable to Alleroed Boelling and Holocene is built up, surprisingly initiated during cold stages. The high ammonium concentrations, which last for several thousand years, suggest that a large retreat of the ice sheet occurred. Pollen data from northwestern Canada [Schweger, 1989] indicate a climate even warmer than present at least between 60,000 and 105,000 yrs B.P. (i.e between stages 4 and $5 c$ ) and there are indications that at certain times the whole of western Canada down to the Hudson Bay was ice free [Andrews et al., 1983]. This is also suggested by Legrand and deAngelis [this issue] due to high concentration of the short-living acetate found in this time period. As shown during the transition into the Holocene, this species substantially affects Greenland only after the almost complete retreat of the ice sheet [Legrand and deAngelis, 1995]. During the first part of the Late Weichsel effects of cold stages on the biomass still seem to be reversible since it apparently redevelops during warm stages over a timescale of millenia. However, mean Holocene ammonium concentrations are no more reached during these stages, indicating smaller fluctuations of the Laurentide ice sheet.

Around the glacial maximum, no increase in source strength of ammonium is observed during warm stages. We conclude that no pronounced change in glaciation of the NA continent occurred during this time period.

\section{Summary and Conclusion}

In this paper we presented ammonium data measured along a ccntral Grcenland ice core covering a complete glacial-interglacial cycle. The contribution of ammonium from biomass burning, from anthropogenic emission, and from soil and vegetation emissions (i.e., background ammonium) are estimated. The variations in the record are discussed in terms of changes in transport and deposition mechanisms and changes in source regions and source strength. We find the following conclusions:

1. There is no obvious correlation between area burned in Canada, which is the most relevant source region for ammonium reaching central Greenland, and ammonium summer fluxes; however, a minimal area burned is needed for a given ammonium flux. We conclude that on a longterm basis the spike record (i.e., biomass-burning record) will be significant of the fire activity in the source area provided that the circulation pattern does not change. This holds true most probably for the Holocene. We conclude that biomass burning contributes between 10 and $40 \%$ to the ammonium deposited on the ice sheet and that the fire activity on the NA continent is decreasing throughout the Holocene.

2. Ammonium in central Greenland shows no overall anthropogenic increase, but a doubling of springtime concentrations over the last 40 years, which can be explained by the influence of Eurasian sources and the enhanced long-range transport associated with high $\mathrm{SO}_{2}$ and $\mathrm{NO}_{x}$ emissions.

3. No trend over the last 300 years is observed in summer, suggesting that anthropogenic ammonia emissions in the relevant source region (northern NA) are negligible.

4. The decreasing trend in the ammonium background concentration during the Holocene is correlated to the temperature record in the source region.

5. A low contribution of low "winter" concentrations 
during early to mid-Holocene agrees with results from general circulation models showing an enhanced winter warming during this time period west from the Laurentide ice sheet.

6. The high ammonium concentrations found in $\mathrm{YD}$ indicate that no cold event took place on the NA continent, as also suggested by other paleorecords.

7. We conclude that continental biogenic species do not necessarily evolve parallel to the climate indicated by the $\delta^{18} \mathrm{O}$ ice record. Instead, we suggest that ammonium reflects an aspect of the biomass history of the NA continent.

8. Very low ammonium concentrations are found at the time of the maximum extent of the Laurentide ice sheet. We suggest that the very low concentrations found immediately after the Eemian indicate that the Laurentide ice sheet was already built up at this stage.

9. Furthermore, we suggest that the sometimes pronounced variations in the ammonium fluxes along the glacial age reflect fluctuations in the ice cover of the NA continent. Large retreats of the Laurentide ice sheet must have occurred especially in marine isotopic stages $5 \mathrm{a}$ and $5 \mathrm{c}$.

Acknowledgments. The deep ice core at Summit was obtained by the Greenland Ice Core Project (GRIP) and ESF associate program, with Belgium, Denmark, France, Germany, Great Britain, Iceland, Italy, and Switzerland participating. The laboratory work was supported by the Swiss National Science Foundation and the Department of Energy. We thank Eric Wolff, Dietmar Wagenbach, Willem Asman, and an anonymous reviewer for their helpful comments.

\section{References}

Alley, R. B., et al., Abrupt increase in Greenland snow accumulation at the end of the Younger Dryas event, $\mathrm{Na}$ ture, 362, 527-529, 1993.

Anderson, T. W., and L. B. Brubaker, Holocene vegetation and climate histories of Alaska, in Global Climates Since the Last Glacial Maximum, pp. 386-400, Univ. Minn. Press, Minneapolis, 1993.

Anderson, T. W., R. W. Mathewes, and C. E. Schweger, Holocene climatic trends in Canada with special reference to the hypsithermal interval, in Quaternary Geology of Canada and Greenland, edited by R. J. Fulton, pp. 520528, Geol. Surv. of Can., Canada, 1989.

Andreae, M. O., et al., Biomass-burning emissions and associated haze layers over amazonia, J.Geophys.Res, 93, $1509-1527,1988$.

Andrews, J. T., W. W. Shilts, and G. H. Miller, Multiple deglaciations of the Hudson Bay lowlands, Canada, since deposition of the Missinaibi (last interglacial?) formation, Q.Res, 19, 18-37, 1983.

Asman, W. A. H., B. Drukker, and J. A. J., Modelled historical concentrations and depositions of ammonia and ammonium in Europe, Atmos. Environ., 22, 725-735, 1988.

Asman, W. A. H., and A. J. Jansson, A long range transport model for ammonia and ammonium in Europe, Atmos. Environ., 21, 2099-2119, 1987.
Bard, E., M. Arnold, R. G. Fairbanks, and B. Hamelin, ${ }^{230} \mathrm{Th}-{ }^{234} \mathrm{U}$ and ${ }^{14} \mathrm{C}$ ages obtained by mass spectrometry on corals, Radiocarbon, 35, 191-199, 1993.

Bolzan, J. F., and M. Strobel, Accumulation-rate variations around Summit, Greenland, J. Glaciol., 40(134), 56-66, 1994.

Boulton, G. S., and C. D. Clark, A highly mobile Laurentide ice sheet revealed by satellite images of glacial lineations, Nature, 346, 813-817, 1990.

Brimblecombe, P., and D. H. Stedman, Historical evidence for a dramatic increase in the nitrate component of acid rain, Nature, 298, 460-462, 1982.

Busenberg, E., and C. C. Langway, Jr., Levels of ammonium, sulfate, chloride, calcium and sodium in snow and ice from southern Greenland, J.Geophys.Res, 84, 1705$1779,1975$.

Charles, C. D., D. Rind, J. Jouzel, R. D. Koster, and R. G. Fairbanks, Glacial-Interglacial changes in moisture sources for Greenland: Influences on the ice core records of climate, Science, 263, 508-511, 1994.

Clarke, R. J., H. Coates, and S. F. Lincoln, A fluorescence stopped-flow kinetic study of the displacement of 2-[(2Bis[caboxylmethyl]amino-5-methylphenoxy)methyl]-6methoxy-8- bis[carboxylmet hyl]aminoquinoline (quin-2) from its $\mathrm{Ca}^{2+}, \mathrm{Pr}^{3+}, \mathrm{Tb}^{3+}, \mathrm{Dy}^{3+}$ and $\mathrm{Yb}^{3+}$ complexes by ethylenedinitrilotetraacetate (EDTA) in aequous solution, Inorgan. Chim., 153, 21-24, 1988.

Cooperative Holocene Mapping Project (COHMAP) members, Climatic changes of the last 18,000 years: Observations and model simulations, Science, 241, 1043-1052, 1988.

Cunningham, J., and E. D. Waddington, Airflow and dry deposition of non-seasalt sulfate in polar firn: Paleoclimatic implications, Atmos. Environ., 17/18, 2943-2956, 1993.

Dansgaard,W. et al., Evidence for general instability of past climate from a 250-kyr ice core record, Nature, 64, 118$120,1993$.

Davidson, C. I., J.-L. Jaffrezo, M. J. Small, P. W. Summers, M. P. Olson, and R. D. Borys, Trajectory analysis of source regions influencing the South Greenland ice sheet during the Dye 3 gas and aerosol sampling program, Atmos. Environ., 17/18, 2739-2749, 1993.

Dawson, G. A., Atmospheric ammonia from undisturbed land, J.Geophys.Res, 21, 2739-2749, 1977.

Eicher, U., and U. Siegenthaler, Palynological and oxygen isotope investigations on late glacial sediment cores from Swiss lakes, Boreas, 5, 109-117, 1976.

Fairbanks, R. G., A 17,000-year glacio-eustatic sea level record: Influence of glacial melting rates on the Younger Dryas event and deep-ocean circulation, Nature, 342, 637$642,1989$.

Franzen, L. G., Are wetlands the key to the ice-age cycle enigma?, Ambio, 23, 300-308, 1994.

Frenzel, B., M. Pecsi, and A. A. Velichko, Atlas of Paleoclimates and Paleoenvironments of the Northern Hemisphere, Geogr. Res. Inst., Budapest, 1992.

Fuhrer, K., A. Neftel, M. Anklin, and V. Maggi, Continuous measurements of hydrogen peroxide, formaldehyde, calcium and ammonium concentrations along the new GRIP ice core from Summit, Central Greenland, Atmos. Environ., 12, 1873-1880, 1993.

Genfa, Z., and P. K. Dasgupta, Fast fluorometric measurement of aequeous ammonium ion in a flow injection system, Anal. Chem., 61, 408-412, 1989.

Greenland Ice Core Project (GRIP) members, Climate instability during the last interglacial period in the GRIP core, Nature, 364, 203-207, 1993.

Grootes, P. M., M. Stuiver, J. W. C. White, S. Johnsen, and J. Jouzel, Comparison of oxygen isotope records from the 
GISP2 and GRIP Greenland ice cores, Nature, 366, 552$554,1993$.

Hansson, M., Detecting changes in climate and atmospheric composition with tracers in arctic ice caps, $\mathrm{Ph}$. D. thesis, Stockholm University, 1993.

Heidam, N. Z., The composition of the Arctic aerosol, Atmos. Environ., 2, 329-343, 1984.

Herron, M. M., Impurity sources of $\mathrm{F}^{-}, \mathrm{Cl}^{-}, \mathrm{NO}_{3}^{-}$, and $\mathrm{SO}_{4}^{2-}$ in Greenland and Antarctic precipitation, J.Geophys.Res, 87, 3052-3060, 1982.

Hov, O., and B. A. Hjollo, Transport distance of ammonia and ammonium in northern Europe: Its relation to emissions of $\mathrm{SO}_{2}$ and $\mathrm{NO}_{x}$, J.Geophys.Res, 99, 18735-18748, 1994.

Hughes, T. J., G. H. Denton, B. G. Andersen, D. H. Schilling, J. L. Fastook, and C. S. Lingle, Areal extent of late Wisconsin-Weichselian ice sheet, in The Last Great Ice Sheets, edited by G. H. Denton and T. J. Hughes, pp. 275-318; John Wiley and Sons, New York, 1981.

Huntley, B., and I. C. Prentice, Holocene vegetation and climates of Europe, in Global Climates Since the Last Gacial Maximum, pp. 136-168, Univ. of Minn. Press, Minneapolis, 1993.

Irving, P. M. (Ed.), Acidic deposition: State of Science and Technology, Volume 1-28, Washington, D. C., National Acid Precipitation Assessment Program (NAPAP), 1990.

Jaffrezo, J.-L., J. E. Dibb, R. C. Bales, and A. Neftel, Current status of atmospheric studies at Summit (Greenland) and implications for future research, in Ice core studies of Global Biochemical Cycle, edited by R. Delmas, NATOASI, pp. 427-458, Springer-Verlag, New York, 1995.

Johnsen; S., H. B. Clausen, W. Dansgaard, K. Fuhrer, N. Gundestrup, C. U. Hammer, P. Iversen, J. Jouzel, B. Stauffer, and J. P. Steffensen, Irregular glacial interstadials recorded in a new Greenland ice core, Nature, 359, 311-313, 1992.

Johnsen, S., W. Dansgaard, and J. W. C. White, The origin of arctic precipitation under present and glacial conditions, Tellus, 41B, 452-468, 1989.

Kagenow, J., Kinetic determination of magnesium and calcium by stopped flow injection analysis, Anal. Chim. Acta, 514, 125-127, 1982.

Koerner, R. M., and D. A. Fisher, A record of Holocene summer climate from a Canadian high arctic ice core, $\mathrm{Na}$ ture, 343, 630-631, 1990.

Laj, P., J. M. Palais, and H. Sigurdsson, Changing sources of impurities to the Greenland ice sheet over the last 250 years, Atmos. Environ., 14, 2627-2640, 1992.

Langford, A. O., F. C. Fehsenfeld, and W. Zachariassen, Gaseous ammonia fluxes and background concentrations in terrestrial ecosystems of the United States, Global Biochem. Cycl., 4, 459-483, 1992.

LeBel, P. J., S. A. Vay, and P. D. Robert, Ammonia and nitric acid emissions from wetlands and boreal forest fire, in Global Biomass Burning, edited by J. S. Levine, pp. 225-229, MIT Press, Cambridge,Mass., 1991.

Legrand, M., Sulfur derived species in polar ice: A review, in Ice Core Studies of Global Biochemical Cycles, edited by R. Delmas, NATO-ASI, pp. 91-120, Springer-Verlag, New York, 1995.

Legrand, M., and M. deAngelis, Origins and variations of light carboxylic acids in polar precipitation, J.Geophys.Res, 100, 1445-1462, 1995.

Legrand, M., and M. deAngelis, Light carboxylic acids in Greenland ice: Record of past forest fires and vegetation emission for boreal zone, J.Geophys.Res,; this issue.

Legrand, M., M. deAngelis, T. Staffelbach, A. Neftel, and B. Stauffer, Large perturbations of ammonium and organic acids content in the Summit Greenland ice core, fingerprint from forest fires?, Geophys. Res. Lett., 19, 473-475, 1992.

Legrand, M., and R. J. Delmas, Soluble impuritics in four Antarctic ice cores over the last 30,000 years, Ann. Glaciol., 10, 116-120, 1988.

Lövblad, G., J. W. Erisman, and D. Fowler, Models and Methods for the Quantification of Atmospheric Input to Ecosystems, in Nord. Seminar Arbejdsrapp., edited by N. of Minist., Volume 573, Copenhagen, 1993.

Martin, P., 40,000 years of extinctions on the "planet of doom", Palaeogr. Palaeoclimatol. Palaeoecol., 82, 187201, 1990.

Mayewski, P. A., G. H. Denton, and T. J. Hughes, Late Wisconsin ice sheets in North America, in The Last Great Ice Sheets, edited by G. H. Denton and T. Hughes, pp. 67-178, Univ. of Maine, 1981.

Mayewski, P. A., G. Holdsworth, M. J. Spencer, S. Whitlow, M. Twickler, M. C. Morrison, M. C. Ferland, and L. D. Meeker, Ice core sulfate from three northern hemisphere sites: Source and temperature forcing implications, $A t$ mos. Environ., 27A, 2915-2919, 1993.

Mayewski, P. A., W. B. Lyons, M. J. Spencer, M. Twickler, W. Dansgaard, D. Koci, C. I. Davidson, and R. E. Honrath, Sulfate and nitrate concentrations from a South Greenland ice core, Science, 232, 975-977, 1986.

Mayewski, P. A., L. D. Meeker, S. Whitlow, M. S. Twickler, M. C. Morrison, R. B. Alley, P. Bloomfield, and K. Taylor, The atmosphere during the Younger Dryas, Science, 261, 195-197, 1993.

Mayewski, P. A., et al., Changes in atmospheric circulation and ocean ice cover over the North Atlantic during the last 41,000 years, Science, 263, 1747-1751, 1994.

Mitchell, J. F. B., N. S. Grahame, and K. J. Needham, Climate simulations for 9000 years before present: Seasonal variations and effect of the Laurentide ice sheet, J.Geophys.Res, 93, 8283-8303, 1988.

Mylona, S., Trends of sulfur dioxide emissions, air concentrations, and depositions of sulfur in Europe since 1880, Norw. Meteorol. Inst.,Oslo, Norway, 1993.

Neftel, A., J. Beer, H. Oeschger, F. Zürcher, and R. C. Finkel, Sulfate and nitrate concentrations in snow from South Greenland 1895-1978, Nature, 314, 611-613, 1985.

Nodop, K., Weiträumige Verteilung und zeitliche Entwicklung säurebildender Spurenstoffe in Europa, 19781985, Volume 81, Inst. Meterol. Geophys., Univ. Frankfurt/Main, Germany, 1990.

Palais, J. M., and M. Legrand, Soluble impurities in the Byrd Station ice core, Antarctica: Their origin and sources, J.Geophys.Res, 90, 1143-1154, 1985.

Peterson, G. M., Vegetational and climate history of the western former Soviet Union, in Global Climates Since the Last Gacial Maximum, pp. 169-193, Univ. of Minn. Press, Minneapolis, 1993.

Quinn, P. K., T. S. Bates, J. E. Johnson, D. S. Covert, and R. J. Charlson, Interactions between the sulfur and reduced nitrogen cycles over the central Pacific ocean, J.Geophys.Res, 416, 405-416, 1990.

Rasmussen, K. L., H. B. Clausen, and T. Risbo, Nitrate in the Greenland ice sheet in the years following the 1908 Tunguska event, Icarus, 58, 101-108, 1984.

Ritchie, J. C., Past and present vegetation of the far northwest Canada, Univ. of Toronto Press, Toronto, Ontario, Canada, 1984.

Ritchie, J. C., and S. P. Harrison, Vegetation, lake levels, and climate in western Canada during the Holocene, in Global Climates Since the Last Gacial Maximum, pp. 401414, Univ. of Minn. Press, Minneapolis, 1993.

Schlesinger, W., and A. E. Hartley, A global budget for atmospheric ammonia, Biogeochemistry, 15, 191-211, 1992. 
Schwander, J., A. Neftel, H. Oeschger, and B. Stauffer, Measurements of direct current conductivity on ice samples for climatological application, J. Phys. Chem, 87, 4157-4160, 1987.

Schweger, C. E., Paleoecology of the western Canadian ice-free corridor, in Quaternary Geology of Canada and Greenland, edited by R. J. Fulton, pp. 491-498, Geol. Surv. of Can., Canada, 1989.

Seiler, W., and P. J. Crutzen, Estimates of gross and net fluxes of carbon between the biosphere and the atmosphere from biomass burning, Clim. Change, 2, 207-247, 1980.

Sigg, A., K. Fuhrer, M. Anklin, and T. Staffelbach, A continuous analysis technique for chemical trace species in polar ice cores, Environ. Sci. Technol., 28, 204-209, 1994.

Silvente, E., and M. Legrand, Ammonium to sulfate ratio in aerosol and snow of Greenland and Antarctic regions, Geophys. Res. Lett., 20, 687-690, 1993.

Steffensen, J. P., Analysis of seasonal variation in dust, $\mathrm{Cl}^{-}$, $\mathrm{NO}_{3}^{-}$, and $\mathrm{SO}_{4}^{2-}$ in two central Greenland ice cores, $A n n$. Glaciol., 10, 171-177, 1988.

Stocks, B. J., The extent and impact of forest fires in northern circumpolar countries, in Global Biomass Burning, edited by J. S. Levine, pp. 197-202, MIT Press, Cambridge, Mass., 1991.

Sutton, M. A., W. A. H. Asman, and J. K. Schjorrin, Dry deposition of reduced nitrogen, Tellus, 46B, 255-273, 1994.

Talbot, R. W., K. M. Beecher, R. C. Harriss, and W. R. Cofer III, Atmospheric geochemistry of formic and acetic acids at a midlatitude temperate site, J.Geophys.Res, 93, 16531-16543, 1993.

Talbot, R. W., A. S. Vijgen, and R. C. Harriss, Soluble species in the Arctic summer troposphere: Acidic gases, aerosols, and precipitation, J.Geophys.Res, 97, 16381652, 1992.

Terasmae, J., and N. C. Weeks, Natural fires as an index of paleoclimate, Can. Field Nat., 92(2), 116-125, 1979.

Thompson, R. S., C. Whitlock, P. J. Bartlein, S. P. Harrison, and W. G. Spaulding, Climatic changes in the western United States since 18,000 yr b.p., in Global Climates Since the Last Glacial Maximum, pp. 468-513, Univ. of Minn. Press, Minneapolis, 1993.
Vincent, J.-S., and V. K. Prest, The early Wisconsinan history of the Laurentide ice sheet, Geogr. Phys. Q., 2, 199-213, 1987.

Warneck, P., Chemistry of the Natural Atmosphere, Acad., San Diego, Calif., 1988.

Webb, III, T., P. J. Bartlein, S. P. Harrison, and K. H. Anderson, Vegetation, lake levels and climate in eastern North America for the past 18,000 years, in Global Climates Since the Last Glacial Maximum, Univ. of Minn. Press, Minneapolis, 1993.

Webb, III, T., W. F. Ruddiman, F. A. Street-Perrott, V. Markgraf, J. E. Kutzbach, P. J. Bartlein, H. E. Wright, Jr., and W. L. Prett, Climatic changes during the past 18,000 years: Regional syntheses, mechanisms, and causes, in Global Climates Since the Last Glacial Maximum, Univ. of Minn. Press, Minneapolis, 1993.

Whitehead, D. C., and D. R. Lockyer, Decomposing grass herbage as a source of ammonia in the atmosphere, Atmos. Environ., 23, 1867-1869, 1989.

Whitlow, S., P. Mayewski, J. Dibb, G. Holdsworth, and M. Twickler, An ice-core-based record of biomass burning in the Arctic and Subarctic, 1750-1980, Tellus, $46 B$, 234-242, 1994.

Whitlow, S., P. A. Mayewski, and J. E. Dibb, A comparison of major chemical species: Seasonal concentration and accumulation at the South Pole and Summit, Greenland, Atmos. Environ., 23, 2045-2054, 1992.

Wolff, E. W., Nitrate in polar ice, in Ice Core Studies of Global Biochemical Cycle, edited by R. Delmas, NATOASI, pp. 195-224, Springer-Verlag, New York, 1995.

M. Anklin, and K. Fuhrer, Physics Institute, University of Bern, Sidlerstrasse 5, 3012 Bern, Switzerland. (e-mail: kfuhrer@climate.unibe.ch)

M. Legrand, Laboratoire de Glaciologie et Geophysique de l'Environnement, CNRS, 38402 Saint Martin d'Heres, France. (email:mimi@glacio.grenet.fr)

A. Neftel and T. Staffelbach, Federal Research Institute for Agricultural Chemistry, 3097 Liebefeld, Bern, Switzerland. (cmail:Neftela@schw155.fac.admin.ch)

(Received January 21, 1995; revised September 13, 1995; accepted September 13, 1995.) 